UNITED STATES ARMY-BAYLOR UNIVERSITY PROGRAM IN HEALTHCARE ADMINISTRATION

\title{
AN ANALYSIS OF THE IMPACT OF TOTAL QUALITY MANAGEMENT ON EMPLOYEES
}

\section{GRADUATE MANAGEMENT PROJECT}

Submitted to:

LIEUTENANT COLONEL JODY R. ROGERS, Ph. D.

February 1997

\section{By}

PATRICK C. BARRETT

USA MEDDAC

FORT KNOX, KENTUCKY 40121-5520

DTC QUATIT TWEPTED 4 


\section{ACKNOWLEDGMENTS}

I would like to acknowledge the unknown author of this TQM tale:

Once upon a time, an American company and a Japanese company decided to have a competitive boat race.

Both teams practiced long and hard to reach peak performance for the big day. They both felt as ready as they could be.

The Japanese team won by a mile.

The American team became discouraged by the loss and morale began to sag. The American management decided that the reason for the crushing defeat had to be found. The "Continuous Improvement Team" was established to investigate the problem and recommend the appropriate corrective action.

The results showed that the Japanese team had eight people rowing and one person steering, whereas, the American team had one person rowing and eight people steering.

The American company Steering Committee immediately hired a consulting firm to do a study of the management structure. After some time and millions of dollars, the consulting firm concluded that too many people were steering and not enough were rowing.

The American team's management structure was totally reorganized. The new structure included 3 Steering Directors, 3 Steering Managers, 2 Steering Supervisors, and 1 Rower. Included in the reorganization plan was a new performance standard which gave empowerment and enrichment to the rower in order to develop an incentive for him to row harder.

The next year the Japanese team won by 2 miles.

Humiliated, the American company laid-off the rower to "cut costs"; sold all the paddles; canceled all capital investments for new equipment; ceased development of a new improved canoe; gave a "superior performance" award to the consulting firm; and distributed the money saved as bonuses to senior executives. 


\begin{abstract}
The roots of Total Quality Management (TQM) date back to post-World War II Japan when management theorists such as Deming and Juran developed ideas in America but were shunned by American industries. They took their ideas to Japan where they were wholeheartedly accepted and implemented, ultimately bringing Japan to its economic pinnacle. The industries' implementation of TQM is due to the belief that it will lead to higher quality patient care, improved patient satisfaction, better employee morale, and lower cost service delivery (Boerstler 1996).

Ireland Army Community Hospital (IACH) began to transition from a traditionally organized facility to a nontraditionally organized facility under the auspices of TQM in 1992. Traditional departments such as Department of Nursing were dissolved and reorganized under functional teams who reported to an executive team. The support services were divided among the three deputies (Deputy Commander for Clinical Services, Deputy Commander for Patient Services, and the Deputy Commander for Administration). The three clinical teams were designed to be self-managed and empowered to improve patient care processes. The philosophy of this reorganization was to facilitate the total quality management theory through management philosophies taught by such gurus as W. Edwards Deming and Joseph M. Juran.

This study analyzed the impact of TQM on the employees' attitudes. The study utilized a two part questionnaire with five demographic questions in Part I, and Part II contained twentytwo questions using a five-point Likert scale and six questions using a dichotomous scale. The questions were divided into general opinion and TQM questions. The respondents who claimed participation in the TQM program were compared to the respondents who did not participate in the program. The working hypothesis was that TQM has had a positive impact on the employees' attitude and this should be evident in the analyses by a statistically significant difference between participants and nonparticipants.

The results of the study indicate that the TQM program is not having a positive impact on the employees' attitude. There were few statistically significant $(p<.01)$ differences in the bivariate and multivariate analyses. The bivariate analysis identified only three (of thirteen) statistically significant items and the multivariate analyses identified only two (of twenty-two) marginally statistically significant $(p<.05)$ items. These results should not be an indictment of the TQM program but an indication of the direction of the current program. The implementation of a TQM program can take years to be fully realized and other internal and external forces have bearing on the impact of the implementation of TQM. IACH can pursue several options ranging from staying with the status quo, dedicating more resources to the program, or reorganizing the current organizational structure.
\end{abstract}




\section{TABLE OF CONTENTS}

ACKNOWLEDGMENTS $\ldots \ldots \ldots \ldots \ldots \ldots \ldots \ldots \ldots \ldots \ldots \ldots \ldots \ldots$ iii

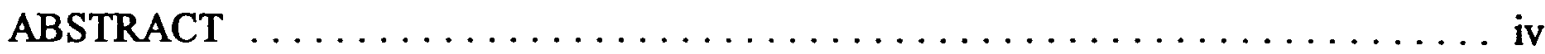

TABLE OF CONTENTS $\ldots \ldots \ldots \ldots \ldots \ldots \ldots \ldots \ldots \ldots \ldots \ldots \ldots$

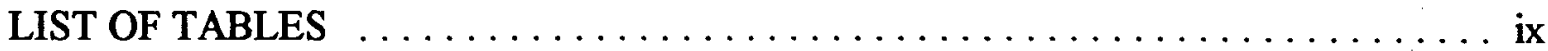

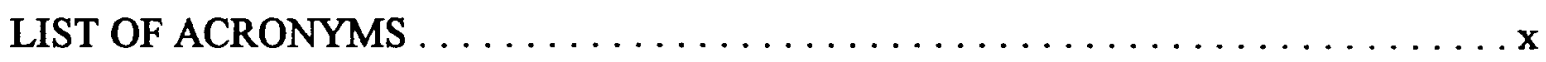

CHAPTER 1

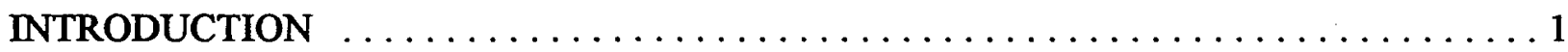

CONDITIONS WHICH PROMPTED THE STUDY $\ldots \ldots \ldots \ldots \ldots \ldots \ldots \ldots$

STATEMENT OF THE PROBLEM $\ldots \ldots \ldots \ldots \ldots \ldots \ldots \ldots \ldots \ldots \ldots \ldots \ldots$

LITERATURE REVIEW $\ldots \ldots \ldots \ldots \ldots \ldots \ldots \ldots \ldots \ldots \ldots \ldots \ldots \ldots \ldots \ldots \ldots$

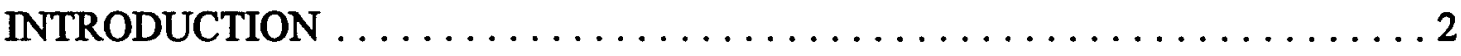

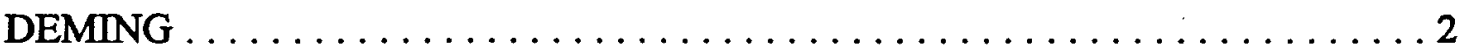

FOURTEEN POINTS $\ldots \ldots \ldots \ldots \ldots \ldots \ldots \ldots \ldots \ldots \ldots \ldots$

SEVEN DEADLY DISEASES $\ldots \ldots \ldots \ldots \ldots \ldots \ldots \ldots \ldots$

PHIIOSOPHY $\ldots \ldots \ldots \ldots \ldots \ldots \ldots \ldots \ldots \ldots \ldots \ldots \ldots \ldots \ldots \ldots \ldots \ldots$

APPRECIATION FOR A SYSTEM $\ldots \ldots \ldots \ldots \ldots \ldots \ldots \ldots \ldots \ldots$

KNOWLEDGE ABOUT VARIATION $\ldots \ldots \ldots \ldots \ldots \ldots \ldots \ldots$

THEORY OF KNOWLEDGE $\ldots \ldots \ldots \ldots \ldots \ldots \ldots \ldots \ldots \ldots$

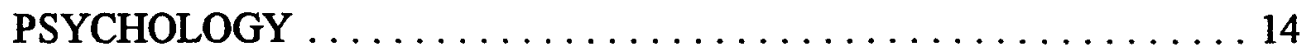

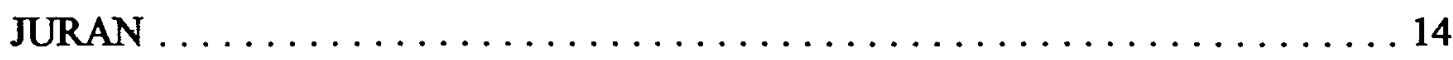

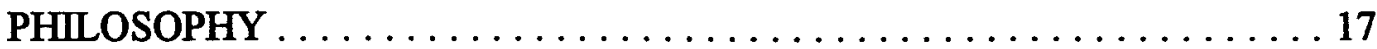


QUALITY PLANNING $\ldots \ldots \ldots \ldots \ldots \ldots \ldots \ldots \ldots \ldots \ldots \ldots \ldots \ldots \ldots \ldots$

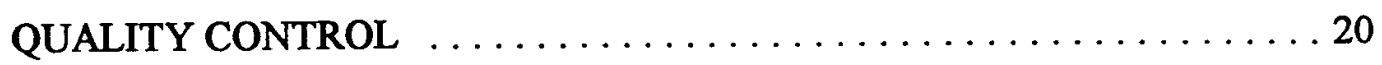

STRATEGIC QUALITY MANAGEMENT $\ldots \ldots \ldots \ldots \ldots \ldots \ldots \ldots 21$

TOTAL QUALITY MANAGEMENT $\ldots \ldots \ldots \ldots \ldots \ldots \ldots \ldots \ldots \ldots \ldots \ldots$

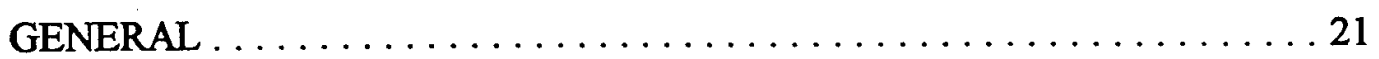

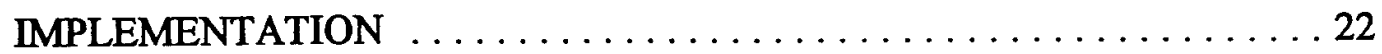

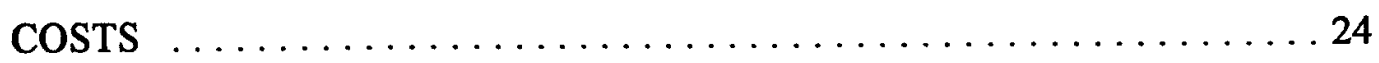

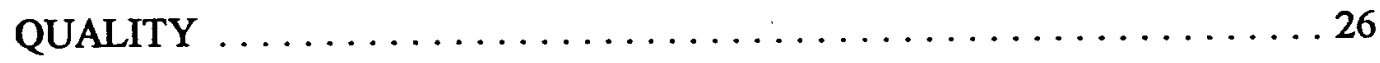

PATIENT SATISFACTION $\ldots \ldots \ldots \ldots \ldots \ldots \ldots \ldots \ldots \ldots \ldots \ldots \ldots \ldots$

EMPLOYEE SATISFACTION . . . . . . . . . . . . . . . . 29

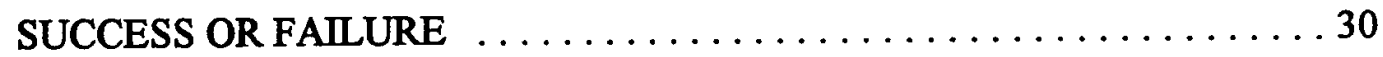

TQM IN THE MILITARY $\ldots \ldots \ldots \ldots \ldots \ldots \ldots \ldots \ldots \ldots \ldots \ldots \ldots \ldots$

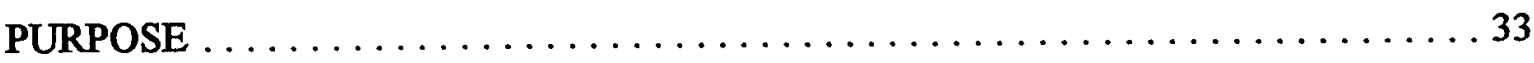

CHAPTER 2

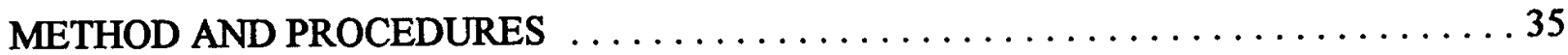

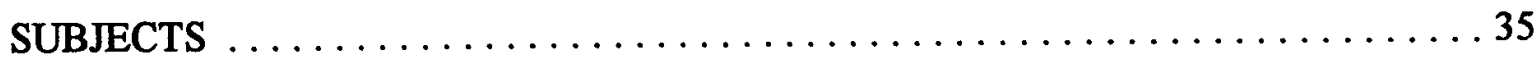

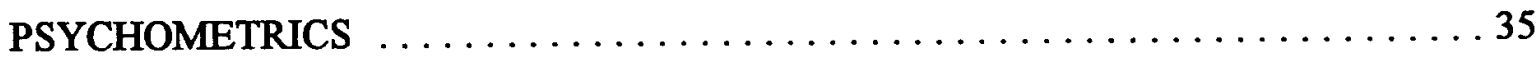

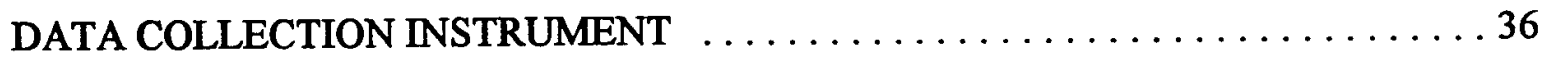

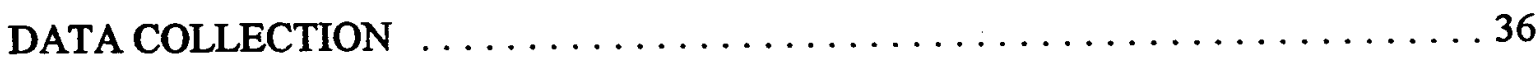

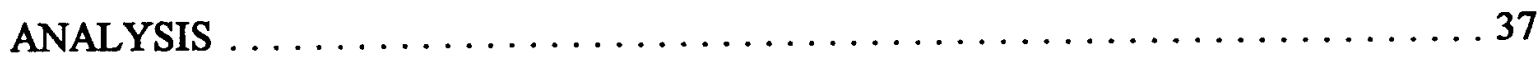

CHAPTER 3

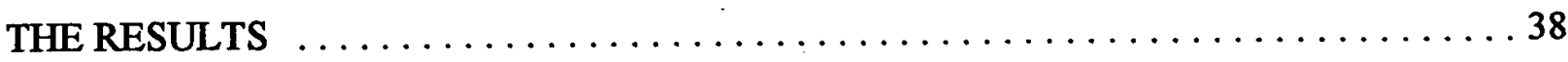


SURVEY

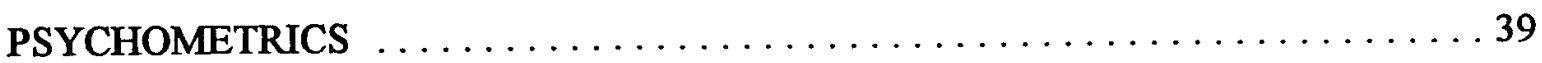

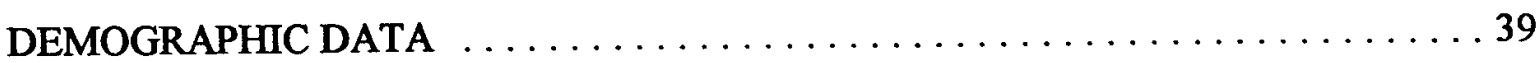

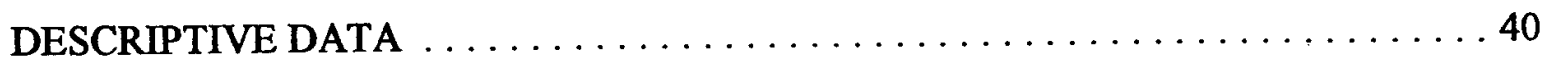

BROAD EFFECTS OF THE TQM PROGRAM $\ldots \ldots \ldots \ldots \ldots \ldots \ldots \ldots \ldots$

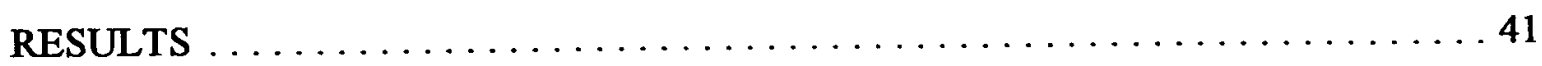

ADDITIONAL SUBGROUP ANALYSIS $\ldots \ldots \ldots \ldots \ldots \ldots \ldots \ldots \ldots \ldots \ldots$

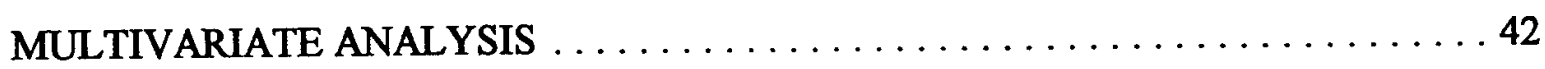

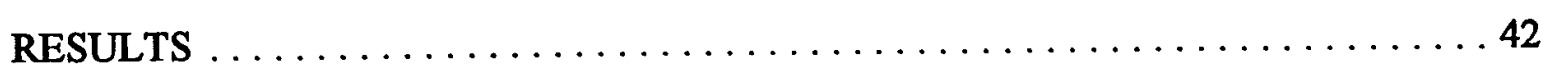

CHAPTER 4

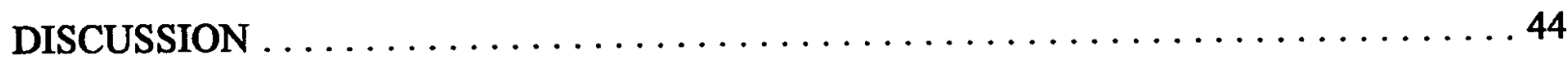

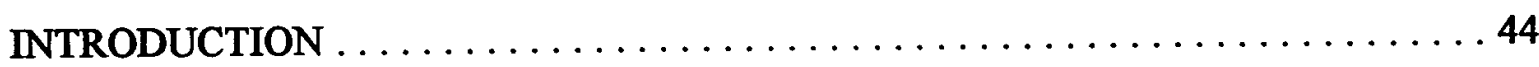

PREVIOUS STUDIES $\ldots \ldots \ldots \ldots \ldots \ldots \ldots \ldots \ldots \ldots \ldots \ldots \ldots \ldots \ldots$

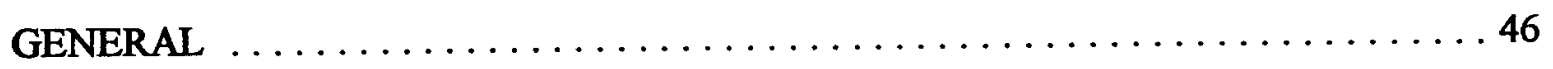

CHAPTER 5

CONCLUSIONS AND RECOMMENDATIONS $\ldots \ldots \ldots \ldots \ldots \ldots \ldots \ldots \ldots \ldots$

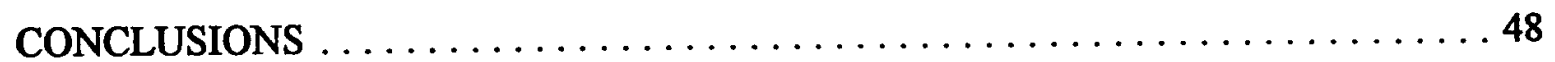

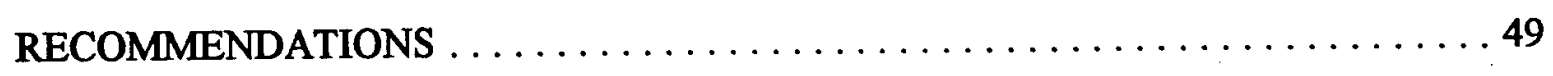

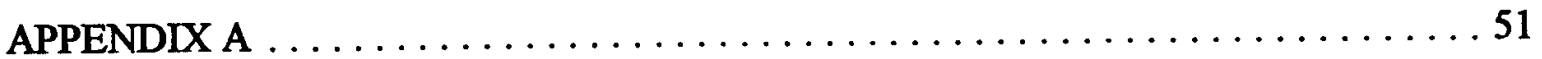

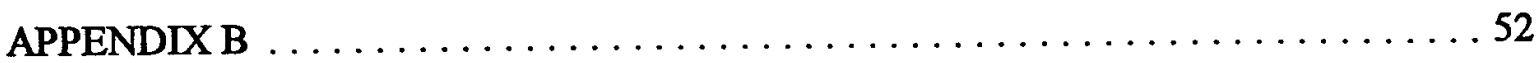

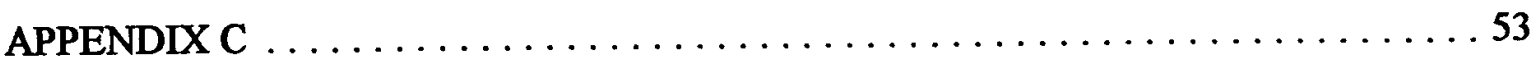

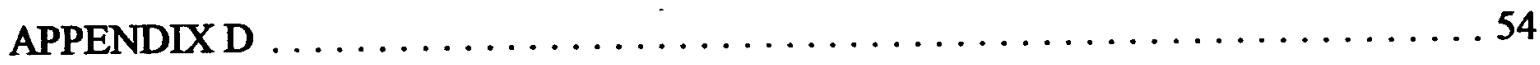

vii 


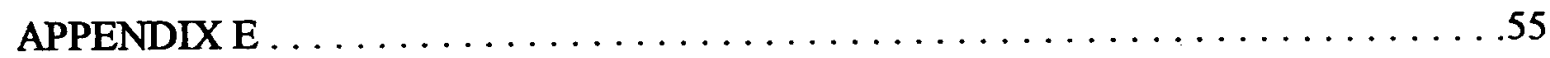

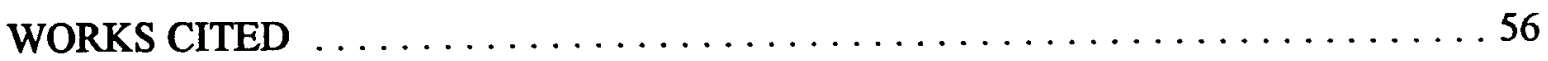




\section{LIST OF TABLES}

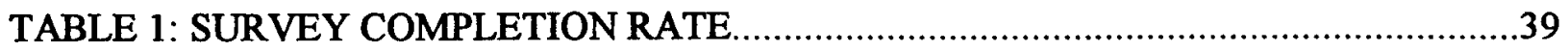

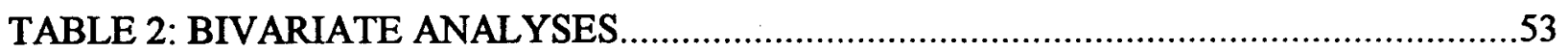

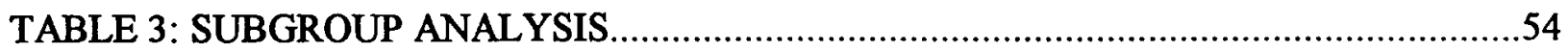

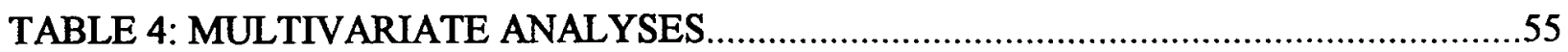




\section{LIST OF ACRONYMS}

Army Performance Improvement Criteria (APIC)

Army Regulation (AR)

Command Sergeant Major (CSM)

Continuous Quality Improvement (CQI)

Deputy Commander for Administration (DCA)

Deputy Commander for Clinical Services (DCCS)

Deputy Commander for Patient Services (DCPS)

Department of Defense (DoD)

Executive Quality Council (EQC)

Executive Steering Council (ESC)

Full Time Equivalent (FTE)

Fort Knox Partnership Council (FKPC)

Ireland Army Community Hospital (IACH)

Joint Commission on Accreditation of Healthcare Organizations (JCAHO)

Japanese Scientists and Engineers (JUSE)

Medical Department Activity (MEDDAC)

Military Health Services System (MHSS)

Navy Personnel Research and Development Center (NPRDC)

North Atlantic Regional Medical Command (NARMC)

Process Action Team (PAT) 
Process Enhancement Team (PET)

Quality Workforce Board (QWB)

Reduction in Force (RIF)

Statistical Program for Social Sciences (SPSS)

Statistical Quality Control (SQC)

Strategic Quality Management (SQM)

Total Quality Leadership (TQL) 


\section{CHAPTER 1}

\section{INTRODUCTION}

\section{CONDITIONS WHICH PROMPTED THE STUDY}

Ireland Army Community Hospital began to transition from a traditionally organized facility to a nontraditionally organized facility under the auspices of Total Quality Management (TQM) in 1992. Traditional departments such as Department of Nursing were dissolved and reorganized under functional teams who reported to an executive team. The support services were divided among the three deputies (Deputy Commander for Clinical Services, Deputy Commander for Patient Services, and the Deputy Commander for Administration). The three clinical teams were designed to be self-managed and empowered to improve patient care processes. The philosophy of this reorganization was to facilitate the total quality management theory through management philosophies taught by such gurus as W. Edwards Deming and Joseph M. Juran.

\section{STATEMENT OF THE PROBLEM}

Ireland Army Community Hospital has been organized under a TQM philosophy for more than four years. An assessment of the impact of this TQM philosophy upon the organization is essential to determine if it has made a positive impact on the employees. 
Measuring the effect of total quality management on the employees will provide the executive team with feedback on the success and drawbacks of the design for future use. Additionally, this study will provide information for other facilities in the Military Health Services System (MHSS) on the usefulness of TQM as a management tool.

\section{LITERATURE REVIEW}

\section{INTRODUCTION}

The roots of TQM date back to post-World War II Japan when management theorists such as Deming and Juran developed ideas in America but were shunned by American industries. They took their ideas to Japan where they were wholeheartedly accepted and implemented, ultimately bringing Japan to its economic pinnacle. The industries' implementation of TQM is due to the belief that it will lead to higher quality patient care, improved patient satisfaction, better employee morale, and lower cost service delivery (Boerstler 1996). This literature review will discuss the major theories advocated by two of the more renowned quality management gurusDeming and Juran. It will also discuss the implementation, costs, quality, patient satisfaction, employees' satisfaction, and the success or failure associated with TQM. Lastly, it will review the

military's attempt at TQM and, more specifically, that of Fort Knox and Ireland Army Community Hospital.

\section{DEMING}

The most notable guru on the teachings of management is Dr. W. Edwards Deming. Dr. Deming was born in 1900 and raised on a Wyoming homestead. He became 
interested in statistics and the workplace while studying for his Ph.D. in physics at Yale. In his early works, he first used something called "statistical control" while monitoring a study on workers' performance. He also developed sampling techniques, in the 1930's, for the U.S. Census. Dr. Deming, during World War II, taught statistical quality control to defense plant personnel and to government procurement officers concerned about the quality in their military purchases. His teachings led to the implementation of statistical quality control (SQC) in numerous U.S. factories but this did not last due to the lack of real competition and a preference for a more traditional approach (i.e., scientific management). This led American corporations to the rule-bound, top heavy structures that were not committed to quality but to short-term profits and higher stock prices. The major obstacle to Deming's philosophy is the key to total quality management - total dedication at the upper management levels.

Dr. Deming, in 1947, was summoned by General MacArthur's headquarters to assist in planning a census of the Japanese population. Dr. Deming discovered the Japanese to be very receptive to his ideas and, in 1950, he was asked by the Union of Japanese Scientists and Engineers (JUSE) to expound on his ideas. Eventually, Deming met with the presidents of Japan's twenty-one leading industries where he elaborated on his ideas of conducting consumer research, producing goods with a market years from now, and the premise that the consumer was the most important part of the product line. Japan embraced Dr. Deming's teachings which led to a 180-degree turn in the quality of Japanese products (the paradigm shift).

Deming impressed the Japanese industry so much that, in 1950, the Deming Prize was created. It consisted of the Deming Prize for individuals and the Deming Application Prizes for large and small companies, individuals, and factories. Initially, these prizes were based on SQC 
but in the late 1970 's they were broadened to include total quality control based on Dr. Deming's later teachings. Even today, Japanese companies compete to maintain quality control through commitment from top level management using Quality Circles (employee groups that meet regularly to help solve problems), an active employee suggestion system, statistical methods, a long-range plan for constant improvement, multiple training programs, and a real sensitivity to customers and suppliers. It would not be until 1979 when Dr. Deming's theories would catch the attention of American companies.

\section{FOURTEEN POINTS}

Dr. Deming developed his theories through his teachings in Japan in the 1950's to what he now calls his "Fourteen Points," which are the basis for the transformation of American industry (Deming 1982).

1. Create constancy of purpose for improvement of product and service. This addresses the problems of today and tomorrow. The problems of today encompass maintenance of quality of the product, regulation of output, employment, profits, sales, service, public relations, forecasting etc. (Deming 1982). The problems of the future command first and foremost constancy of purpose and dedication to improvement of competitive position to keep the company alive and to provide jobs for its employees (Deming 1982). The establishment of constancy of purpose means acceptance of obligations such as innovation, resources for research and education, and continual improvement of the design of product and service.

2. Adopt the new philosophy. American industry must overcome the Seven Deadly Diseases (see page 9) and obstacles. These obstacles include the hope for instantaneous results; 
the supposition that solving problems, automation, gadgets, and new machinery will transform industry; obsolescence in schools; poor teaching of statistical methods in industry; misuse of computers; fallacy of zero defects; the supposition that it is only necessary to meet specifications; and inadequate testing of prototypes. America cannot tolerate mistakes, defects, the wrong person or material for the job, poor supervision etc. The fourteen points must be adopted and the deadly diseases and obstacles overcome.

3. Cease dependency on mass inspections. In essence, mass inspection is planning for defects because it is too late, ineffective, and costly. Quality improvement should be a result of improving the production process. Mass inspection does not improve quality nor guarantee quality. The use of mass inspection, with very rare exception, is unreliable, costly, and ineffective. The inspectors will fail to agree with each other until the process is brought under statistical control.

4. End the practice of awarding business on the basis of price tag alone. Decisions to buy a product or service based upon price tag alone place no measure on the quality. The purchasing manager must look at the lowest total cost not the lowest initial cost of material. There are numerous advantages to a single source and long-term relationship with a supplier such as innovation and economy. The use of a single vendor simplifies accounts and paperwork and lowers the investment and total inventory.

5. Improve constantly and forever the system of production and service. The process of improvement must be continual and management must lead the way. Teamwork in the design phase is fundamental and management must convey the intent to the team. There must be continual improvement in manufacturing by working with vendors ultimately reducing to one 
vendor and improving the process through better allocation of human resources. Improvement of the process is not "putting out fires." Dr. Deming advocates the Kanban system (delivery just in time) due to the discipline behind it - processes in control; quality, quantity, and regularly predictable.

6. Institute Training. Training in America must be revamped and employees taught about the company from the incoming material to the customer. Employees must be trained through a competent training program as opposed to on-the-job training or learning from workers or instructors. The training program must be seen as an investment of the company's human resources. The inhibitors to good work must be removed (refer to Point 12) and training for a job must teach the customers' needs (Deming 1982). It is far easier to make the initial investment to train an employee right the first time then to retrain the employee.

7. Adopt and institute leadership. "The job of management is not supervision, but leadership" (Deming 1982). William Bennis and Burt Nanus in the book Leaders (1985) stated "historically leaders have controlled rather than organized, administered repression rather than expression, and held their followers in arrestment rather than in evolution . . . Managers are people who do things right and leaders are people who do the right thing" (Bennis \& Nanus 1985). It is common place for supervisors who do not know the work they supervise. The barriers must be removed such as emphasis on numbers, not quality; turning out products quickly, not properly; ignoring the suggestion of workers; problems with incoming material; proper tools; and too much time spent on rework.

8. Drive out fear. Bennis and Nanus pointed out that leaders should administer expression rather than repression. Fear stifles innovation and prevents employees from making 
suggestions due to possible retribution. Additionally, fear can lead to the inability to serve the best interests of the company by adhering to specific rules or to meet a production quota. Employees must feel confident with management to be able to point out problems and make suggestions.

9. Break down barriers between staff areas. Departments or divisions optimize their own work areas but do not work as a team for the company. Competition between departments does not lend itself to communication and cooperation, and is actually detrimental to the company's mission. Teams should have a multi-disciplinary nature, not only develop expertise, but also commitment and ownership. The key, though, is that management must create a system that allows teamwork to function.

10. Eliminate slogans, exhortations, and targets for the workforce. The use of catchy slogans and posters aimed at the work force to motivate them to be more productive only adds to employee frustration and resentment. "They arise from management's supposition that the production workers could, by putting their backs into the job, accomplish zero defects, improve quality, improve productivity, and all else that is desirable" (Deming 1982). This type of "motivation" only further exemplifies that management does not understand the problems.

11. Eliminate numerical quotas. Numerical quotas for work dates back to Taylorism and Scientific Management which Frederick W. Taylor advocated in his work The Principles of Scientific Management (1911). Although quotas may serve a purpose for predicting costs, they are an obstacle to improvement of quality and productivity. An established quota can lead to poor quality due to defective items. This affects pride of workmanship and leads to rework, which costs the organization money. 
12. Remove barriers that rob people of pride of workmanship. These barriers affect two groups of people: management, or people on salary, and hourly workers. The barrier to management, or salaried employees, is the annual rating of performance, or merit rating. Quotas are one of the barriers to hourly workers. Workers must meet a specific quota and, in some cases, knowingly produce defective products so supervisors meet the quota. People are treated like commodities, with management making halfhearted attempts by instituting employee involvement, employee participation, and quality of work-life programs. These attempts start out with a bang but slowly die as workers find out the program is a smoke screen by management to hide personnel problems.

13. Encourage education and self-improvement for everyone. Management and the workforce must keep current on new methods. The workforce should not fear that improvements (Point 8) will result in lost jobs. Employees should know up front from management that quality will not cost jobs. Management should retrain employees for new jobs as new skills are needed.

14. Take action to accomplish the transformation. It will take total commitment from the top management team through a plan of action to accomplish this transformation. Management must understand the Fourteen Points, the Deadly Diseases (explained next), and the obstacles in order to accomplish this transformation. The transformation must be explained to the workforce, that the change is necessary and the employees must be involved in that change. A flow diagram of the process will divide the work into stages. Every stage has a customer which is the next stage. Each stage should work with the preceding stage and the following stage for optimization. Dr. Deming advocates the Shewhart Cycle as a tool to follow for improvement of a stage or to find a special cause detected by statistical signals. The first step is to determine what 
change may improve the process by developing a plan using data and tests. Next, the tests or change should be executed, preferably on a small scale. Third, observe the effects of the change or tests. Finally, study the results and repeat the tests if necessary while looking for side effects.

\section{SEVEN DEADLY DISEASES}

Dr. Deming believes that the Seven Deadly Diseases must be addressed in order to transform the Western style of management. The deadly diseases are entrenched in companies of the Western world, a complete shake up is needed to reverse the trend.

1. The crippling disease: lack of constancy of purpose. There must be a total dedication to the new philosophy by upper management to ensure its permeation and acceptance throughout the organization. This means that short term gains such as quarterly dividends should not be the focus. The focus should be on protecting the investment by working continually toward improvement of processes, product, and service that will bring the customer back again (Deming 1982).

2. Emphasis on short-term profits. The emphasis on short-term profits defeats the constancy of purpose. Quarterly dividends can be easily boosted by shipping everything on hand, deferring orders for material and equipment until next quarter, and cutting back on research, education, and training. All of these defeat constancy of purpose and long-term growth. Additionally, companies whose stock falls or rises fear an unfriendly takeover or leveraged buy out.

3. Evaluation of performance, merit ratings, or annual reviews. Most American businesses and the government use the system of annual ratings. It has come to be called 
management by objective but evolves to management by fear. The effects of this can be devastating by promoting short-term performance, annihilating long-term planning, building fear, demolishing team work, and nourishing rivalry and politics. Systems such as merit rating reward those who do well in the system, rather than those who improve the system. Additionally, the merit system is meaningless as a predictor of performance. Evaluation of performance leads to short-term thinking and performance. The employee is relegated to attaining numerical goals or quotas which again deprive the employee of pride of workmanship. The evaluation system stifles teamwork because it is the individual working for the individual's benefit, rather than that of the team or company. In an interview in 1994 , less than three months before his death, Dr. Deming still advocated the elimination of performance evaluations because of his belief that people do what is governed by the system in which they work (Stevens 1994). Thus, evaluations actually measure the interaction between the worker and the system (Stevens 1994).

4. Mobility of management. Most of top management in America stay with an organization for only a few years, hindering long-term planning, and teamwork. In Japan, managers work their way up through the company, and workers are usually with the same company for life.

5. Running a company on visible figures alone. Companies live and breath by the balance sheet, stocks, and dividends. There is little attention paid to quality improvement. Losses occur due to annual ratings and inhibitors to pride of workmanship. Too little attention is paid to employee morale and customer satisfaction.

The last two are prevalent in U.S. industry.

6. Excessive medical costs. The direct cost of medical care to companies is additive to 
the cost of a product. As medical costs continue to rise, this will have an impact on the costs of consumer goods. Additionally, there are numerous other health care costs (indirect) to a company such as counseling, treatment for alcohol and drug impairment, and treatment for injuries on the job.

7. Excessive costs of liability, swelled by lawyers that work on contingency fees. America is one of the most litigious nations on Earth. These costs, like medical care, are factors in the costs of products to the consumer.

\section{PHILOSOPHY}

Dr. Deming's philosophy is based upon the Fourteen Points, the Seven Deadly Diseases, and the obstacles. The mainstay of his approach to making decisions is through the use of statistical analysis, not on hunches or experiences. Deming advocates the use of charts to assist in improving quality of performance. It is vital to base decisions on a statistical analysis, but management and employees must be taught in statistical techniques, gathering data, grouping data, and using this to correct performance. Data gathered properly on workers performance allows for the pinpointing of special causes such as a defective machine tool. Deming suggests the use of charts in improving quality. The Cause-and-Effect chart is used to examine factors that may influence a given situation. The minor causes are grouped around four basic categories: materials, method, manpower, and machines. A flow chart records a sequence of events and suggests the impact of each on the operation. Priorities may be determined by using a pareto chart which charts the various times, for example, of various events. Run charts detect trends relative to time such as sales per month. A histogram finds the most-often-found status of a 
certain variable when an operation is reported over and over. In order to determine the relationship between two variables, a scatter diagram is used. Finally, the Deming Control Chart is used as a continuous guide to constant improvement.

In an interview less than two weeks prior to his death, Dr. Deming still advocated his major theories. He stressed his Fourteen Points, innovation, elimination of performance appraisals, and his system of profound knowledge (Steven 1994). Dr. Deming stated "you can learn a lot about ice and know nothing about water" (Deming 1994). In order to change the system we must obtain an outside view. The four components of the system of profound knowledge address the following: appreciation for a system, knowledge about variation, theory of knowledge, and psychology.

\section{APPRECIATION FOR A SYSTEM}

Deming defined a system as “a network of interdependent components that work together to try to accomplish the aim of the system" (Deming 1994). The interdependence between components requires communication and cooperation between them. Deming's philosophy has discussed how certain practices such as management by objective (MBO) hamper interdependence. He uses an orchestra as a good example of a system of cooperation in which listeners judge not one musician, but how the entire orchestra works together. It is the obligation of each component then to contribute its best to the system with the components negotiating between each other to achieve the aims of the system. 


\section{KNOWLEDGE ABOUT VARIATION}

There will always be variation between people and output, service and product. The fact is, though, that half will be above average and half will be below average. Deming states there are two kinds of variation, the variation that comes from common causes and the variation caused by something special (Stevens 1994). A variation that occurs within the control limits belongs to the system, a common cause. A variation outside the control limits would indicate a special cause.

The mistake is to react to an outcome as if it came from a special cause when it actually came from a common cause of variation or vice versa. A process that is in statistical control allows the performance to be predictable; therefore costs, performance, quality, and quantity are predictable. Shewhart referred to this as a stable state. Processes that are not predictable are in an unstable state.

\section{THEORY OF KNOWLEDGE}

The theory of knowledge maintains that anything management does is based on predictions. Predictions, of course, run the risk of being wrong. Theories provide rational prediction and build knowledge through systematic revision and extension of theory. These theories are based upon comparisons of predictions with observations. Theories are derived from experience and examples on which to base predictions. The use or interpretation of data from tests or experiments is prediction. It is then only in the state of statistical control that statistical theory provides prediction of performance in the immediate future (Deming 1994). In these days of instant communication, information is readily available; but information is not knowledge. Knowledge comes through theory which is based upon this information. 


\section{PSYCHOLOGY}

Managers must understand people, and how they interact with customers and suppliers, the manager and other employees. Managers must be aware of these differences and use them to optimize the abilities of their employees. Employees are motivated in different ways through extrinsic and intrinsic values. Extrinsic motivators help build self-esteem but to the extreme it can crush intrinsic motivation (Deming 1994). Norb Keller made a statement on 8 November 1987 in a meeting at General Motors in relation to extrinsic motivators: "If General Motors were to double the pay of everybody commencing the first of December, performance would be exactly what it is now" (Deming 1994). The phenomenon of over justification stipulates that current systems of reward for an act or achievement done for sheer pleasure or self satisfaction may be meaningless or actually a discouragement. A manager must understand what is important to an individual; a sign of appreciation may mean far more than a monetary award.

\section{JURAN}

Joseph M. Juran was born in 1901 in Braila, Romania to the son of a shoemaker. He emigrated to the United States in 1912 and received a Bachelors Degree in Electrical Engineering at the University of Minnesota and a Doctor of Jurisprudence from Loyola University in Chicago.

Dr. Juran, in the 1940s, advocated the Pareto Principle, the law of vital few and the trivial many, which is now a basic problem-solving "tool" of the quality movement. Juran's definition of quality as "fitness for use" brought the customers needs and desires into the picture. This led to the concept of total quality management in which quality is not just a matter of ensuring that a product conforms to certain specifications, but is a force that ought to drive all 
management practices and business processes in an organization. He published the first edition of Quality Control Handbook in 1951, and in 1954 accepted an invitation by Japan to conduct a series of lectures. Juran expanded on his theories called continuing quality improvement, and described the structure of the management process a company needed to execute the concept. This management process was further explained in his 1964 work entitled Managerial Breakthrough.

In 1979, Juran established the Juran Institute of Wilton, Connecticut, which provides consulting services on quality. He retired as the Chief Executive Officer in 1987, the same year he served as the original board overseeing the Malcolm Baldrige Quality Awards.

Juran addressed the broad management aspects of quality because firms did not know how to manage for quality. His philosophy addressed the human elements organization, communication, and coordination. He identified three basic steps to progress: structure annual improvements combined with devotion and a sense of urgency, massive training programs, and upper management leadership. Juran believes less than twenty percent of quality problems are caused by workers, and more than eighty percent by management. Managers not only need training to be technically proficient, but also to oversee quality improvements. As in Deming's philosophy, top management must be included in this training to ensure cohesiveness between departments.

Juran advocates the use of quality circles to improve communication between management and labor. He, like Deming, has a disdain for the use of slogan campaigns aimed at motivating the work force. This approach fails to set specific goals or establish plans to meet the goals while failing to provide the needed resources. Juran differs from Deming in that he 
advocates statistical process control but believes it can lead to a tool-oriented approach.

Additionally, he does not favor sole-sourcing for important purchases (product related items such as raw material or components). The fear is that a single source may not have its competitive edge in quality, cost, or service. Juran also does not believe that "quality is free" as Philip B. Crosby insinuates in his work Quality is Free (1979). This is due to the law of diminishing returns in which quality reaches an optimum point beyond which conformity is more costly than the value of the quality obtained.

In the area of procurement, Juran recognized that improvement cannot come from the organization alone and must include the suppliers. The quality of competing contractors must be assessed and vendors surveyed to ensure consistent quality. Communication between the suppliers and the organization is critical especially in light of the increasing number of foreign firms, which can lead to barriers such as language, cultural differences, and differing technical standards.

Juran advocates the following ten steps to quality improvement:

1. Build awareness of the need and opportunity for improvement.

2. Set goals for improvement.

3. Organize to reach the goals (establish a quality council, identify problems, select projects, appoint teams, designate facilitators).

4. Provide training.

5. Carry out projects to solve problems.

6. Report progress.

7. Give recognition. 
8. Communicate results.

9. Keep score.

10. Maintain momentum by making annual improvement part of the company's regular systems and process.

\section{PHILOSOPHY}

Juran believes quality is maintained through leadership which requires it to be incorporated in the overall strategic plan and unprecedented upper management leadership to manage for quality. As previously stated, Juran defines quality as fitness for use meaning the product or service must meet the needs of the customer, provide customer satisfaction, and create sales. This implies that the product or service must be free from deficiencies which cause customer dissatisfaction and increased costs due to rework or responding to customer complaints. There are three essential processes to manage for quality. The first is quality planning to develop the product and process required to meet customer needs. Quality control compares actual quality performance to quality goals and acts on the differences. This is opposed to reworking defective products because of quality deficiencies. The quality improvement will raise the quality of performance to unprecedented "breakthrough" levels.

One of the first steps is to establish a quality council responsible for launching, coordinating, and "institutionalizing" annual quality improvement (Juran 1989). The creators and members of this are from the upper management. The council must publish a statement of their responsibilities explaining the approach and goals of the program. The council maintains the program by establishing quality measures, reviewing progress, ensuring implementation and 
solutions, and appropriately recognizing and rewarding those who make it happen (Juran 1989).

The process of quality improvement is a project-by-project undertaking which follows Juran's suggested sequence:

1. Solicit project nominations from throughout the company. This is accomplished through customer reports, service reports, and accounting data.

2. The nominations are screened to identify a project that will be a visible success. Additional projects should be selected that benefit the company by increasing return on investment, the amount of potential improvement, urgency, ease of technological solution, a healthy product line, and the least resistance to change.

3. The mission statement sets a quantifiable goal for each individual project with a list of projects incorporated in the next years business plan.

4. A team of six to eight people are selected to manage each project. There should be representatives from different departments and upper management. The team does not have a "boss" but a council appointed chairperson and secretary with a trained facilitator to guide and build the team.

5. Team responsibilities are defined in a project mission statement setting out the following steps (Juran 1989):

-Analyze the symptoms.

-Brainstorm to develop theories about causes.

-Test the theories with data analysis.

-Establish causes.

-Assign the appropriate function to develop a remedy. 
-Test the remedy under operating conditions.

-Establish controls to hold the gains.

-Look for ways to apply solutions to other similar problems.

6. There is some type of recognition for completed projects. Rewards in the form of certificates, write-ups in company publications, and dinners to honor project teams motivate the team and provide incentives to future teams.

7. The program for individual and collective projects is continuously evaluated.

\section{QUALITY PLANNING}

A universal approach to launching new products and processes is through quality planning by determining customer's needs and developing the products and processes to meet them. The goal of quality planning is to meet customers' needs with a minimum of dissatisfaction and costly deficiencies. The plan is accomplished on four levels: worker, department, multifunction, and corporate/ divisional. The intricacies of this plan require a stricter approach based on a quality planning "road map.." The first step is to identify the external and internal customers and classify them by significance. The "vital few" would be the big customers (companies, etc.) while the "useful many" would be the smaller customers (individuals). Customers' needs, the second step must be assessed to determine the expectations of the product and what makes the customer buy the competition's product. This can be determined through market research and by talking to the customer. The third step is to develop the product based on the customers' and supplier's needs, meeting the competitions' standards, and minimizing the costs of supplying and using the product. Representatives from suppliers, customers, and 
processors are included during the development phase to assist product planners. The final step is to develop a process able to produce the product features. This process should meet the customers' and supplier's needs and keep costs to a minimum. Another step is to study and apply what is learned from each project such as lessons learned to prevent recurrence of problems on the next project. Additionally, an audit should be conducted to determine if customers' needs were met, the length of cycle time, and how much work had to be redone.

\section{QUALITY CONTROL}

Juran identifies a three-step process to solve the problems that get in the way of meeting goals: evaluate actual performance, compare actual performance to goals, and take action on the differences (Juran 1989). The first step, evaluate the actual performance, requires relinquishing the control, responsibility, and authority to the operating workers. The workers must know the goals, standards, and ways performance is measured in order to detect nonconformance. They must understand the big picture such as the "why" and how their work relates to others. Quality can be incorporated into the process by providing the workers with guidelines. Data summaries will need to be provided to managers to check on the goals affecting the "vital few" customers and control subjects also to detect major trends, threats and opportunities and evaluate individual and group performance. The second step is comparing performance to goals by providing workers with detailed specifications and procedures that identify their goals. The workers can accomplish this through technical measurement and their own observations. The last step is to act on the differences by identifying them. 


\section{STRATEGIC QUALITY MANAGEMENT}

Although many organizations implement a quality program, their programs fail due to the lack of a systematic, structured approach (Juran 1989). Juran suggests Strategic Quality Management (SQM) to provide a structured, company wide method for upper managers to set and meet quality goals. SQM requires incorporating quality goals into the business plan, adopting cultural changes, instituting a new infrastructure, extensive training for managers, and upper management participation. A senior management level quality council must be convened to establish and maintain SQM. This could be the same council overseeing quality or a higher level council. The council will publish a quality policy statement and goals. The goals can be obtained by soliciting and screening nominations and then incorporating them in the business plan. The council must establish appropriate measures for each control subject. Performance measures must be established to allow comparisons and, if units of measurement are not common, common indexes must be set. Again, quality improvement is a project-by-project process, so collective evaluation is limited to summaries such as the number of projects and status, financial results, and persons involved. Upper management must be kept informed of results through standardized reports and unbiased audits. Juran emphasizes that SQM is not an instant fix; it can take up to six years to establish it in an organization.

\section{TOTAL QUALITY MANAGEMENT}

\section{GENERAL}

In a national survey (Barsness et al. 5 December 1993), 68.9 percent of the hospitals 
indicated they had undertaken a TQM effort to improve the quality of care; the remaining 31.1 percent did not use a formal approach. Of the facilities using TQM, 73.4 percent used it less than two years, 22.5 percent for two to four years, and only 4.1 percent for more than four years. 81.4 percent of large facilities (400 or more beds) used TQM; 74.4 percent of medium-size hospitals (100-399 beds) reported trying TQM. Smaller facilities (6-99 beds) using TQM accounted for only 57.6 percent and were also the most recent adopters, while the larger facilities had the most experience. Some of the senior management barriers noted were: lack of board commitment and support, lack of senior management time commitment, frequent senior leadership turnover, not enough resources committed to the effort, lack of physician support, inadequate employee and management training, insufficient time for staff to attend training, too many priorities, and inadequate consulting support (Barsness et al. 5 December 1993). Some of the organizational infrastructure barriers were the inability of key people to work together, inability to use personnel in new ways, inadequate information systems, inadequate organizational structure, and lack of realistic goals (Barsness et al. 5 December 1993). 28 percent reported using Deming's approach to TQM; 4 percent chose Juran, and 2 percent for Crosby. 26 percent used more than one approach; 18.4 percent used approaches differing from those of Deming, Juran, and Crosby, with 21.2 percent not selecting any approach.

\section{IMPLEMENTATION}

The implementation of TQM often stems from the belief that it will lead to higher quality patient care, improved patient satisfaction, better employee morale, and lower cost service delivery (Boerstler 1996). In an article by Steve Barr (1994), he suggests a ten-step method to 
implement TQM in a facility: educate top management, establish benchmarks, staff education strategy (i.e., consultants), train management, pilot projects, assign facilitators and trainers, target "critical mass," establish a reliable reporting system, communicate progress to employees, and recognize participants and efforts. As noted in the theories of Deming and Juran, management is the key to TQM. Management must not only be committed but educated on TQM. One of the goals of TQM is to empower employees, but the reality is that only management can "give that permission" (Management Leadership Critical to CQI Success 1992). This was evident in the implementation of TQM at Baptist Medical Center in Columbia, South Carolina, where managers were taught how to empower their employees (Management Leadership Critical to CQI Success 1992). The transition to TQM is, in reality, a paradigm shift. Management must plan for quality by correcting root causes of organizational dysfunction when it occurs rather than constantly "putting out fires." The same is true for physicians who succeed by planning for health and by defining and treating underlying diseases rather than merely treating symptoms when health fails. The entire implementation is a change in the organizational culture. The focus is to strive to continuously look for ways of improving quality and satisfying patient and customer needs. The focus is on solving problems as opposed to assigning blame.

In a study by Boerstler et al. (1996) of ten facilities who were in different stages of implementing TQM, he validated previous findings but also identified some contradictions. It confirmed previous findings from the literature (JCAHO 1992, Kosta 1992, Wakefield 1993) on the difficulty of involving physicians in TQM. Most of the sites, even those beginning with clinical projects, had a small minority of the medical staff involved in TQM. Consistent with previous literature (Berwick 1989, Godfrey et al. 1992, JCAHO 1992), the hospitals cite a lack of 
adequate information (or an inadequate information system) as a barrier to TQM. They report a lack of access to data relating to ambulatory services, home health, and nursing home care.

Additionally, there were problems with consistency in definitions of terms. The study identifies six violations of what was thought to be conventional wisdom. One, the first project does not have to be an administrative project. Two, documented results do not necessarily take years but can be as early as 90-100 days. Third, total senior management participation is not necessarily vital in the implementation. Fourth, it is not imperative to begin with a clear vision of quality improvement. Fifth, establishing a Quality Council is not an essential first step. Finally, organization wide training is not necessary for a consistent implementation strategy.

\section{COSTS}

One of the purposes for initiating TQM is to lower costs (Boerstler 1996). In a national survey (Barsness et al. 1993), hospitals with a TQM program (69 percent) scored significantly higher on the financial outcome scale than hospitals without a program. The facilities with TQM programs attribute greater cost savings. to quality improvement efforts than do non-TQM hospitals. The most substantial savings were in large TQM hospitals with 400 beds or more. Teaching hospitals experience greater cost savings due to TQM. System member TQM hospitals also noted greater cost savings than non-system TQM hospitals as a result of TQM . Overall, the findings suggest that TQM hospitals are more likely to report cost savings than hospitals not involved in TQM activities. One of Deming's theories is to look at suppliers to reduce costs. In one facility, an outgrowth of the hospital's TQM initiative was a vendor certification program which collected data on the accuracy of supply shipments, verified received shipments, and 
eventually eliminated the extensive receiving process and its related paperwork (Lumsdon 1992). This eliminated poor vendors, retained the good suppliers, and reduced the hospital's costs. Another facility established a formal preventive maintenance program for equipment with the help of alliance partner Abbot Laboratories. The estimated savings was about $\$ 50,000$ annually through less-costly routine checkups rather then waiting to make extensive repairs once equipment broke down (Lumsdon 1992). Additionally, the streamlined ordering and distribution system with alliance members eliminated inventory, realizing a one-time savings of $\$ 100,000$. TQM can save money for all types of health related organizations. A network of alcohol-anddrug-treatment centers called Fountain Centers implemented TQM and erased a $\$ 600,000$ operating loss in twelve months (TQM Spells Financial Turnaround for Minnesota Centers 1994). The network reduced its full time employees (FTEs) by fifteen, including most of the operations middle management, and received it's first commendation-level status from JCAHO. Nursing facilities implementing TQM can also cut costs (Saidan 1993). Saidan's consulting firm, Saidan Consulting Group, has noted that TQM programs saved up to a 25 percent reduction in support service labor hours equaling $\$ 100,000$ per 120-bed nursing facility, an average of 40 percent reductions in cost for each process studied ( $\$ 10,000$ per administrative employee), and a reduction in staff turnover that could save a 120 -bed facility about $\$ 34,000$ annually. Dr. Ernie Rutherford, a partner in five dialysis centers, is a devotee of Dr. Deming's statistical process control and continuous quality improvement. Four years after implementing TQM, marginal costs per dialysis treatment fell 35 percent, netting an additional $\$ 500,000$ for each center (Larkin 1996). Cost savings can be realized through TQM programs, but as will be discussed later, not all programs produce cost savings for a myriad of reasons. 


\section{QUALITY}

Another noted reason for implementing TQM is to improve the quality of care to the beneficiaries. Participation in TQM is required by JCAHO. The implementation of TQM in health care was still in the infancy stage in the late 1980s until the National Demonstration Project on Quality Improvement in Health Care. This project included professionals in the quality field, academia, industry, and health care who were paired up to tackle projects. The results of the 21 projects were stunning and were described in a work by Dr. Donald M. Berwick titled Curing Health Care (1991). Another part of the project was the establishment of a network of 32 hospitals for the purpose of sharing information, known as the Quality Management Network. This network holds annual meetings and has become the gravitational center of the TQM movement in health care (Banham 1993).

One of the major concepts of TQM is the improvement of processes which leads to lower costs, better quality, customer satisfaction, and employee satisfaction. There are two types of quality - technical quality (providers meeting the standard of care) and customer service quality. The way health care providers and administrators judge the quality of health care from the way patient's make the same assessment. Health care providers and administrators need to be cognizant of that difference (Licata et al. 1995). The staff of the Florida Hospital Medical Center, a 1,342 bed acute care center, was committed to process improvement to improve the quality of care to its patients. Patients often received food they had not ordered, with a 12 percent error rate (Banham 1993). A quality team analyzed all aspects of food service and in only four months reduced the error rate to less than 2 percent. On the clinical side, the hospital 
noticed an increase in costs for respiratory care. The nursing focus group developed a "care map" that delineated care for each day of the patient's stay. An Anchorage, Alaska medical center was experiencing a high volume of patient complaints in the emergency room due to waiting time (up to six hours), staff rudeness, and an overall lack of communication (Banham 1993). An analysis determined 80 percent of the patients were not seriously ill, and 70 percent of those patients were cared for between 9:00 a.m. and 6:00 p.m. The solution was to divide the emergency room in half- one side for the seriously ill, and another for less seriously ill patients. More staff was scheduled during the day than at night. The facility did not need to hire more health care providers, just use them more efficiently. The results were a 75 percent reduction in patient complaints, a reduction in wait time from six hours to 65 minutes, and happier employees.

\section{PATIENT SATISFACTION}

Juran defined quality as fitness for use in which the product or services meet the needs of its customers and provide customer satisfaction. Again, a patient may receive the highest quality of care from the technical standpoint, but if the patient was treated rudely or waited too long it could result in an unsatisfied customer. In a study conducted by the White House Office of Consumer Affairs, mismanagement of an organization's service delivery was shown to have devastating effects. The average organization does not receive complaints from 96 percent of its dissatisfied customers, therefore, for every complaint there is approximately 26 additional undocumented problems. Of customers who complain, 54-70 percent will return if the problem was resolved (Johnson et al. 1992). Additionally, the average dissatisfied customer, will tell nine to ten other people. The long-term success of a health care organization is reliant upon patient 
satisfaction and loyalty. The patient's satisfaction or dissatisfaction is an attitude derived from the confirmation or disconfirmation of expectations (Bendall \& Powers 1995). Patient loyalty is a result of satisfaction with a service. In health care, customer satisfaction is closely related to perceived quality of care such as good communication and attentiveness to patient concerns by the provider (Bendall \& Powers 1995).

A couple of ways to address patient satisfaction are to effectively use patient satisfaction data and to include the customers (patients) in the organization. The intent of patient satisfaction data is to improve quality and increase satisfaction levels (Schweikhart \& Strasser 1994) but, despite significant investments, some organizations are unsuccessful in learning how to use data effectively. Patients who provide feedback but see no resolution feel the organization does not value their opinions and that the patient satisfaction survey was a marketing hoax (Schweikhart \& Strasser 1994). The main problem noted by Schweikhart and Strasser was that staff members did not possess basic technical skills in analysis, interpretation, and application of data. Deming's philosophy is that decisions should be based upon data analysis; it is illogical for an organization to collect data and not analyze it. The inclusion of the patient in the organization empowers the patient, as the employee is empowered in the organization through TQM. In the United Kingdom, the advice of patients was sought through patient participative groups and community health councils (Lawrence 1992). A study on the ombudsman's complaint program (Ziegenfuss \& O'Rourke 1995) determined that it was an effective program that empowered the customer and went beyond putting out fires by analyzing problems within the context of the organization as a whole. Patient satisfaction data can be obtained in numerous ways such as focus groups, the critical incident method, direct observation, content analysis of letters and comments, written 
surveys, archival studies, telephone surveys, and interviews. Patient satisfaction will not be achieved if data is not analyzed and patients are not included in the process.

\section{EMPLOYEE SATISFACTION}

Total Quality Management also strives to improve employee satisfaction and morale

through empowerment. Employee involvement in operating decisions, including planning, goal setting and monitoring of performance allows buy in to the system (Deming 1982). This is the idea behind the use of multi disciplinary teams working toward consensus through the involvement of all the disciplines studying process improvement. In a study of a large Midwestern academic medical center (Counte et al. 1992), participants in the TQM program were more likely to have higher job satisfaction, more favorable perceptions of the organization's climate, positive opinions regarding the organization, and stronger endorsements of the basic tenets of TQM philosophy. The study surveyed 7,382 employees with a 70.8 percent return rate $(n=5,174)$ using a 14-page survey covering job satisfaction, organization climate, general opinions, and TQM opinions (Counte et al. 1992). It is important to realize that employee satisfaction is as critical as customer satisfaction because both are customers - internal and external. It is those employees who deliver satisfaction to your external customers. A lot of attention is paid to collecting and analyzing patient satisfaction, data but the same is true for employee satisfaction surveys. The Malcolm Baldrige National Quality Award guidelines have key indicators of employee satisfaction to gauge how a company's performance objectives were being met through human resources planning and management. 


\section{SUCCESS OR FAILURE}

The literature review has discussed all of the successes of TQM but it would be unrealistic not to address the failures. Failures are common when the wrong approach is taken to solve problems. In an article by John Welsh (1993), he addressed the technique of approaching the problem from a linear versus a holistic approach. Managers attacking the problem from a linear approach address the problem as an isolated event and temporarily fix the problem. The holistic approach addresses the problem by involving the staff and analyzing the whole process, ultimately, arriving at solutions that address the system rather than on a specific problem. TQM is likely to fail when it is seen as a quick fix, in response to competition, a marketing gimmick to attract patients, employers, or insurers, or because it is the newest fad. A report by Chi Systems (Sherer 1994) indicated that most of the 4,500 hospitals that have heavily invested in TQM have yet to realize their financial goals. The development and implementation of TQM may require an expenditure of $\$ 50,000$ to $\$ 300,000$ or more while organizations try to find ways to realize a

return. Inconsistencies in returns have been attributed to organizations not being prepared for the time, money, and leadership commitment necessary for TQM to work (Sherer 1994). In a survey of laboratories by the Medical Laboratory Observer (Maher 1994), TQM helped to foster greater comraderie and a sense of team spirit but it failed to stimulate major improvements in services due, in part, to a lack of commitment among management personnel. In that survey, personnel criticized the large amount of paperwork needed to implement the concept of TQM (Maher 1994). One of the failures noted in the survey of 3,303 hospitals (Barsness et al. 5 December 1993) was the lack of physician involvement which may address a key reason for TQM projects 
tackling administrative rather than clinical processes. The study noted that only 10 percent of the active staff physicians participated in quality improvement projects (Barsness et al. 5 December 1993). TQM pioneer Dr. Brent C. James stated that 90 percent of the hospitals he visited were afraid to approach their physicians (Oberman 1994). One reason that the jury is still out on the benefits of TQM is that its results are difficult to quantify: the effects of TQM are hard to measure and technically hard to implement. In an article by Counte et al. (1995), the authors agree that, the most important effects of TQM may take a long period to appear. The author did provide an audit framework to depict the type of effort TQM may have on the performance of health care organizations and assessment guidelines that may determine whether TQM activities do make a significant difference.

\section{TQM IN THE MILITARY}

In the early 1980's, well before the fall of communism and the downsizing of the military, the Department of Defense (DoD) began a quality improvement initiative based principally on Deming's philosophy. The initiative began in the early 1980's with the Navy Personnel Research and Development Center (NPRDC) in San Diego, California. A formal memorandum was issued in 1987 by Dr. Robert Costello, former Under Secretary of Defense for Acquisition, outlining how TQM could be implemented in DoD. The following year, Secretary of Defense Frank Carlucci released the DoD Posture on Quality followed by a master plan for implementing TQM across the entire agency (Duffek \& Harding 1993). One of the most successful departments in DoD has been the Department of the Navy. The Navy instituted a

Total Quality Leadership (TQL) Office under then Secretary of the Navy H. Lawrence Garrett III 
in 1989. Since 1993, Navy and Marine Corps commands have achieved more than 20 major quality awards including the Presidential Award for Quality and the first two quality cup awards bestowed by USA Today for government agencies (Kidder \& Ryan 1996). The Navy applied Deming's principles but had to accommodate what was unique about the Navy, such as the chain of command.

The Army established a Total Army Quality (TAQ) program, governed by Army Regulation (AR) 5-1 (1992). This briefly written policy defines the Army's philosophy, vision, and imperatives on continuous process improvement to meet or exceed the expectations of internal and external Army customers. The Total Army Quality program uses the Army Performance Improvement Criteria (APIC) as the framework for improving Army-wide operational performance. The APIC adopted seven major categories of the Malcolm Baldrige National Quality Award: leadership, information and analysis, strategic planning, human resources development and management, process management, business results, and customer focus and satisfaction. Fort Knox has an established TAQ office staffed by three FTEs with the responsibilities of providing TQM training to the post, providing advice to commanders, and preparing the post to meet the APIC. The program is established under the umbrella of the Fort Knox Partnership Council (FKPC). It is run by an Executive Steering Council (ESC) composed of nine members. The ESC has the following responsibilities: identify and prioritize systems needing the attention of the Quality Workforce Boards (QWBs) and Process Action Teams (PATs), set the stage for quality at the organizational level, meet regularly and maintain written minutes, identify and remove organizational barriers to the QWB implementation, create a vision statement for Fort Knox, appoint members of the QWB, and ensure necessary resources for 
Quality Workforce Boards. There are currently three QWBs composed of the different agencies on Fort Knox. Each unit or agency, in turn, has its own QWB that charters or disbands PATs.

Ireland Army Community Hospital, in 1992, decided to reorganize under the TQM philosophy. The reorganization lead to the establishment of teams vice departments. Departments such as Nursing, Primary Care, and Community Medicine were disbanded to form multidisciplinary teams. An Executive Team was established, composed of the Commander, the Deputy Commander for Clinical Services (DCCS), the Deputy Commander for Administration (DCA), the Deputy Commander for Patient Services (DCPS), and the Command Sergeant Major (CSM). The major departments were divided into three clinical teams. All of the mental health related services were formed under Team Behavioral Medicine. The inpatient and surgical services were placed under the Surgical Services Team, with the outpatient services formed under Team Ambulatory Medicine. The TQM Program for the facility is governed by MEDDAC Pamphlet Number 1-1, entitled the Strategic Plan for Transition to Continuous Quality Improvement (CQI). The facility established an Executive Quality Council (EQC) composed of seven members responsible for providing direction for the hospital TQM program. The QWB is composed of eight or more members responsible for the major systems in the facility and implementation of TQM and CQI. Additionally, the QWB establishes and disbands all PATs or Process Enhancement Teams (PETs) in the facility.

\section{PURPOSE}

The purpose of this paper is to determine the effect of TQM on the employees of Ireland Army Community Hospital (IACH). The working hypothesis is that TQM has had a positive 
impact on the employees' attitude and this should be evident in the analyses by a statistically significant difference between participants and nonparticipants. The objectives of the study are to determine if TQM has permeated the organization and to obtain the employee's opinion on the reorganization under a TQM philosophy. 


\section{CHAPTER 2 \\ METHOD AND PROCEDURES}

\section{SUBJECTS}

The target population of this study was the military and civilian employees of Ireland Army Community Hospital (IACH). The study included all ranks from pay grade E-1 to E-9 and all officers from 0-1 to 0-6. It also included all civilian employees GS-1 and above. The study included all professional, paraprofessional, and administrative personnel within the facility. It excluded contract employees, part-time employees, and Veterans Administration employees. Most of the employees were exposed to the facilities TQM program through Cultural Awareness Training (required for all employees) or additional training for facilitators and members of the QWB.

\section{PSYCHOMETRICS}

The survey was composed of two parts. Part one was composed of five demographic questions and part two had twenty-two questions using a five-point Likert scale and a dichotomous six question section. This survey was determined to be reliable in a previous study conducted by Counte et al. (1992) when the five-point Likert scale as measured by Cronbach's alpha exceeded .82 . 


\section{DATA COLLECTION INSTRUMENT}

The survey instrument was composed of two parts. The first part addressed demographic data such as gender, age, race, pay grade, and status (military or civilian). Part two was a 28-question survey relating to the employee's opinion about and knowledge of the facility's TQM program. The responses to the questions were scored on a five-point Likert Scale from strongly agree (1) to strongly disagree (5). All of the questions were recoded so that higher scores reflect more positive opinions. The TQM survey was taken from a six part, fourteen page survey in a study conducted by Counte et al. (1992).

\section{DATA COLLECTION}

The data was collected using a stratified random sample of the pay grades in the facility. A cover letter was attached to the survey to describe its purpose, its confidentiality, and that the survey is completely voluntary. A normal sample size was obtained from the target population of 1,000 employees. A normal sample size was determined to be 80 personnel but, assuming a 50 percent return rate, the sample size was doubled to $160(n=160)$. The two page (including the cover letter) voluntary survey to the identified population was delivered through the hospital distribution system. The survey was designed to be one page, completed in a short amount of time (5-10 minutes), and easily returned through the hospital distribution system. It was desirable to keep the survey to one page, to ensure that it could be filled out in a short amount of time, and to ensure a high return rate. Another reason to keep the survey to one page was so it could be folded in half, stapled, and returned to the sender (return address already preprinted on the reverse side of the survey) without inconveniencing the respondent. 


\begin{abstract}
ANALYSIS
The problem was to ascertain whether the TQM program was affecting employee attitudes while also obtaining a status on the program in the facility. The employees were categorized into two groups. The first group were those employees reporting personal participation in the TQM program. The second group was composed of those employees who were uncertain or that had not been involved in the TQM program.

The statistical analysis was conducted using Statistical Program for Social Sciences (SPSS) version 6.1. A summary of the descriptive statistics provided information such as gender, race, whether the respondent was military or civilian, age, and pay grade (six categories). The first analysis was a statistical comparison between employees who indicated personal participation in the TQM program and those who were nonparticipants or uncertain. The analysis was a T-test using a pooled variance estimate and a two-tailed probability with an alpha level of .01 being selected to indicate a level of statistical significance. The second analysis was a stepwise multiple regression including the five demographic variables. Again, the alpha level was set at .01 to indicate statistical significance.
\end{abstract}




\section{CHAPTER 3}

\section{RESULTS}

\section{SURVEY}

The survey instrument utilized was composed of two parts. The first part addressed demographic data and the second part was a 28-question section which asked the employees questions pertaining to their opinion about and knowledge of the facility's TQM program. The 28-questions were composed of 22 questions using a five-point Likert Scale and six questions using a dichotomous variable (yes, no/ don't know). The Likert Scale was recoded so that higher scores reflected more positive opinions. A normal sample size for the facility's population was determined to be 80 and, assuming a 50 percent return rate, this was doubled to 160 . Table 1 depicts the surveys distributed and the return rate. A stratified random sample of the pay grades in the facility was used to ensure a proportional representation of all employees. As Table 1 depicts, 80 surveys were usable in the analyses, discounting 14 surveys with missing variables (overall return rate of $58 \%$ ). The goal of at least a 50 percent return rate was therefore achieved as the author intended by doubling the sample size. 
Table 1-- Survey Completion Rate

\begin{tabular}{l|l|l|l|l|l}
\hline \multicolumn{7}{l}{ SUR EYS } \\
\hline \hline Survey & $\begin{array}{l}\text { Eligible } \\
\text { Respndents }\end{array}$ & $\begin{array}{l}\text { Proportion } \\
(\%)\end{array}$ & $\begin{array}{l}\text { Surveys } \\
\text { Distributed }\end{array}$ & Respondents & $\begin{array}{l}\text { Percentage } \\
\text { Completed }\end{array}$ \\
\hline E-1 TO E-4 & 133 & $13 \%$ & 22 & 8 & $36 \%$ \\
\hline E-5 TO E-9 & 185 & $19 \%$ & 30 & 14 & $46 \%$ \\
\hline O-1 TO 0-3 & 94 & $10 \%$ & 15 & 4 & $26 \%$ \\
\hline O-4 TO 0-6 & 67 & $7 \%$ & 11 & 11 & $100 \%$ \\
\hline GS 1-8 & 354 & $36 \%$ & 57 & 28 & $49 \%$ \\
\hline $\begin{array}{l}\text { GS 9 \& } \\
\text { Above }\end{array}$ & 156 & $16 \%$ & 25 & 15 & $60 \%$ \\
\hline TOT AL & 989 & $100 \%$ & 160 & $80 *$ & $50 \%$ \\
\hline
\end{tabular}

*This does not include fourteen surveys improperly filled out.

\section{PSYCHOMETRICS}

The survey was distributed using a stratified random sample to ensure proportional representation of all pay grades in the facility. The survey had an overall representation of 50 percent and ranged from 26 percent to 100 percent in the specific categories. A reliability analysis of the survey was conducted on the five-point Likert scale as measured by Cronbach's alpha exceeding .79. The previous study by Counte et al. (1992) measured a Cronbach's alpha exceeding .82 .

\section{DEMOGRAPHIC DATA}

Of the usable surveys, 53.7 percent of the respondents were male and 46.3 percent were female. The race category was composed of 76.3 percent Caucasian, 13.7 percent Black, 1.3 
percent Asian, and 2.4 percent in the 'other' category. The proportions by pay grade are depicted in Table 1. The representation of the pay grade category ranged from 26 percent (O-1 to $0-3)$ to 100 percent (O-4 to O-6). Age of the respondents ranged from 19 years to 61 years with a mean age of 39. The status of respondents (military or civilian) reported 46.3 percent military and 53.7 percent civilian.

\section{DESCRIPTIVE DATA}

Although the six dichotomous variables (questions 23-28) in the survey were not analyzed, it does provide the reader with additional information on the TQM program in the facility. There were 71.3 percent who reported having participated in a TQM program or session offered by IACH. Those who participated in a quality improvement program or session offered by an organization other than IACH was 43.8 percent. Seventy-one percent of the respondents reported that their departments participated in the TQM program. There were 26.3 percent who reported as serving on a PAT and 38.8 percent having worked on a PET. 27.5 percent of the respondents reported that $\mathrm{TQM}$ was making a positive impact within their department.

Participation in TQM was determined to be those respondents who had served on a PAT or PET (43.8 percent).

\section{BROAD EFFECTS OF THE TQM PROGRAM}

A statistical comparison of employees who indicated personal participation in TQM and those who were nonparticipants or uncertain was based on T-tests using a pooled variance estimate with a two-tailed probability. An alpha level of .01 was selected to indicate statistical 
significance such that any observed difference due to chance alone would occur less than one time out of 100. The results are summarized in Appendix C.

\section{RESULTS}

Scores on the nine general opinion questions exhibited no statistically significant differences. The difference in mean scores between those who participated in TQM and those not participating ranged from .48 ( $\mathrm{p}$ value of .063$)$ to .02 ( $\mathrm{p}$ value of .924$)$. The second set of bivariate comparisons of TQM participants and nonparticipants involved thirteen questions related to the tenets of TQM. In general, participants should exhibit greater agreement with these items if the TQM program had a positive impact. Participants in the TQM program exhibited significantly different responses on three of the thirteen questions. Participants were more likely to agree that: they are involved in making decisions that affect their department, they understand the TQM/ quality improvement objectives for their departments, and their supervisors shared a strong commitment to the $\mathrm{TQM} /$ quality improvement process.

\section{ADDITIONAL SUBGROUP ANALYSIS}

The bivariate analysis did not consider the potential confounding effects of major differences in the TQM participation and nonparticipation sample. An analysis was conducted of TQM participation versus nonparticipation across the five demographic variables (see Appendix D): gender, race, status, pay grade, and age. There was one marginally statistically significant $(p<.05)$ in the pay grade category GS 1 to GS 8 . However, TQM participants were more likely to be 40 or over, male, Caucasian, be either in the $0-4$ to $0-6$ or GS 1 to GS 8 pay grades, and overall be in the military. 


\section{MULTIVARIATE ANALYSIS}

A series of multiple regressions was conducted using the nine general opinion questions and the thirteen TQM questions to control for the inequivalences of the groups. These analyses were conducted in two steps. The first analysis included the five demographic variables entered into a multiple regression with the 22 outcome variables. These variables were regressed on the dichotomous variable for TQM participation (participant (1), nonparticipant or don't know (0)). The second analysis was the dichotomous TQM participant variable regressed on each of the 22 outcome variables. The results of these two techniques present the estimated coefficients (effects) of the TQM participation variable using the two techniques- adjusted for all demographic variables and unadjusted. The need for multivariate analyses is displayed in Appendix E. The need to control for potentially confounding effects of the difference in the samples due to the size, sign, and statistical significance of adjusted and unadjusted coefficient differ. The reliance solely on bivariate results could be misleading.

\section{RESULTS}

TQM participation seemed to have a positive effect on a couple of the general opinion questions except the item concerning recommending the facility for care. The item concerning whether surveys evoked change had a negative effect in the adjusted value. None of the values were statistically significant but the adjusted value was marginally statistically significant $(p<.05)$ for the item concerning recommending the facility to work in. In the TQM opinions, TQM participation appeared to have a positive effect on the items concerning customers' needs coming first and wanting to participate in the decision making process. The satisfaction with the TQM 
training program changed to a negative effect in the adjusted value. None of the values were statistically significant but the unadjusted value for supervisors backing TQM was marginally significant though not significant in the adjusted value. 


\section{CHAPTER 4 \\ DISCUSSION}

\section{INTRODUCTION}

The problem was to determine the attitude of IACH employees toward TQM. The methodology to determine this was by comparing the general and TQM opinions of participants and nonparticipants in the facility's TQM program. The hypothesis is that there should be a statistically significant difference between participants and nonparticipants if the program was having a positive impact. This study did not find that to be the case and, instead, found little statistical significance between the two groups. This discussion will cover the previous study by Counte et al. (1992), a study by the North Atlantic Regional Medical Command (NARMC) which included TQM related questions, and a general discussion of the results.

\section{PREVIOUS STUDIES}

In a study conducted by Counte et al. (1992), it determined in the bivariate analysis that seven of the general opinion questions exhibited statistically significant differences for participants and nonparticipants. TQM participants were more likely to recommend the facility to work in and for patient care, express general satisfaction, continue to work at the facility and express an effective upper management, well informed work force, and that surveys evoked change. This 
compared to this author's study which had no statistically significant differences between participants and nonparticipants in the general opinion questions. In Counte et al. (1992), the study determined from the TQM opinion questions that five were statistically significant. Participants were more likely to agree that customers' needs should come first, being involved in job decisions, strong emphasis on teamwork, upper management backing TQM, and awareness of TQM goals. This compared to the author's study which exhibited two statistically significant differences between participants and nonparticipants. Participants were more likely to understand the TQM objectives for the department, and feel their supervisor backed TQM.

In the multivariate analyses conducted by Counte et al. (1992), the study identified all eight items (adjusted and unadjusted) to be statistically significant in the general opinion questions. In the adjusted value, participants were more likely to: recommend the facility to work in, recommend the facility for patient care, general satisfaction, plan to continue to work at the facility, effectiveness of upper management, employees well informed, and value of the survey to communicate and evoke change. This compared to this author's study which exhibited only a marginally statistically significant item for the adjusted value in recommending the facility to work in. In the TQM opinions, six questions (adjusted value) were determined to be statistically significant. These items were customers needs should come first, being involved in job decision making, strong emphasis on teamwork, and being aware of the TQM goals. This author's study exhibited only one item to be marginally statistically significant which were supervisors backing TQM (unadjusted value).

Another study conducted by Eagle Group International (Brown \& Williams 1996) for the Commander, North Atlantic Regional Medical Command (NARMC) studied a variety of 
issues, including TQM. The survey was conducted throughout the command using a ten-page survey with a 6 -point Likert Scale $(1=$ totally disagree to $6=$ totally agree). The survey contained three questions related to TQM. One question was, "Do they understand how their organization's TQM program works?", which IACH had a mean score of 4 (agree) and NARMC a mean score of 3.7 ( 3 equals disagree). The second question asked if their own role and responsibilities in support of the organization's TQM program had been clearly defined, with the IACH facility mean being 3.6 and NARMC's 3.4. The third and last question asked if everybody in their organization was supportive of the TQM program effort, with the IACH facility mean score being 2.9 and NARMC's 3.3.

\section{GENERAL}

Is the facility's TQM program having a positive impact on the employees? This was the research question posed by this study of a normal sample size of a population of more than 1,000 employees in a small sized medical facility that has been utilizing TQM for more than four years. The answer to the question is no. The previous study by Counte et al. (1992) determined that the TQM program at a large academic medical center had a positive impact. The analyses conducted by the author clearly demonstrated through a bivariate and multivariate analyses that took into account possible confounding variables that the current TQM program did not have a positive impact on the employees. The implementation of a TQM program, though, is a long-term effort and results, as noted in the literature review, may not be realized for five to ten years.

The strength of the study was the reliability of the surveying instrument, the sample population, and the analyses. The survey instrument, which was used in the study by Counte et al. 
(1992) determined a Cronbach's alpha that exceeded .82 and this author's study determined a Cronbach's alpha exceeding .79. This provides the reader with an assurance of the reliability of the survey instrument. The sample included all pay grades, military and civilian, and all types of employees to include professional, paraprofessional, and administrative and support personnel which was the intent of using a stratified random sample. Lastly, the analyses conducted demonstrated the need to conduct both a bivariate and multivariate with the multivariate including such confounding variables as demographics.

There were also several weaknesses in the study. The sample size could always be larger to ensure more accuracy. Additionally, there was no opportunity to form a baseline assessment prior to the implementation of the facility's TQM program which could have led (through comparison) to different conclusions. There was also no way to determine the level of training or exposure of the participants to the TQM program. The results could also be attributed to internal and external factors of the facility. The factors could be the continued downsizing of the DOD, the recent announcement by management to conduct a reduction in force (RIF), the implementation of Tricare, and the recent relocation of major services within the facility. Also, an attributable factor could be the mechanism by which the facility chose to facilitate the TQM program which was through a restructuring of the organization from departments to teams. The employees may associate this structure with TQM and may be condemning the structure more than the philosophy of TQM. 


\section{CHAPTER 5}

\section{CONCLUSIONS AND RECOMMENDATIONS}

\section{CONCLUSIONS}

The problem was to determine if the facility's TQM program was having a positive impact on the employee's attitudes. Clearly, the analyses demonstrates the TQM program has not had a positive impact on the employees. The fact that there are few statistically significant difference between participants and nonparticipants substantiates this conclusion. However, this author would not conclude that the TQM program has had a negative effect due to the fact, as stated previously in the discussion, that there was no baseline to compare with this analysis. This analysis clearly indicates that there was no difference between those who have participated in TQM and those who have not. This was not the case in the previous study by Counte et al. (1992) which determined that there was a statistically significant difference between participants and nonparticipants.

This should not imply that the TQM program is a not successful. As stated in the literature review, results from TQM programs can take years to be fully realized. Internal and external forces can facilitate or hinder the implementation and permeation of the philosophy of TQM in an organization. Internal factors such as the commitment of the current leadership, the attitudes of middle managers and supervisors, the training program for new personnel, and the 
continued training for employees. External factors such as the downsizing of the DOD, budget constraints leading to RIFs, and the implementation of Tricare can contribute to employee negative attitudes.

The cold, hard truth is that, as stated in the literature review, TQM is not a panacea for all of an organization's problems. It is a philosophy (not a structure) that must have buy in from top management down to the front line employee. TQM is not for all organizations with some producing monumental gains (both financially and through employee morale) while others invest heavily with negligible or no noticeable gains. The literature review reflects the fact that the jury is still out on the benefits of TQM.

\section{RECOMMENDATIONS}

IACH can pursue several options based upon this study such as staying with the status quo, dedicating more resources to the program, or reorganizing the structure. Of course, status quo is an option with another study (using the same survey instrument) being done to compare with this study as the baseline. Another course would be to dedicate more resources to the TQM program. The resources could be an increase in the staff to enhance the training program or additional funds to pay for training through external sources. A third option, alluded to earlier, would be to restructure the organization along more traditional lines. The main emphasis on TQM would be through new employee training, continuing education through the TQM department, the Quality Workforce Board, and PAT's and PET's. The restructuring option would provide a different mechanism for the implementation and sustainment of the TQM program. Whatever the option chosen, it must be backed by upper management through support 
and emphasizes on the tenets of TQM in order for the program to be successful. 
APPENDIX A- Cover Letter

TO:

You have been randomly selected to complete the attached survey. The purpose of this survey is to determine the MEDDAC employees' opinion of the Total Quality Management program.

You may, if you wish, obtain the overall results of the survey by contacting Captain Patrick Barrett at 9744 . Individual responses will not be released to any other party and will be destroyed after the data is consolidated.

Your participation in this survey is completely voluntary. Upon completion of the survey detach this sheet for your use. Please fold the survey in half, staple, and return to Captain Barrett through the distribution system NLT 13 December 1996. The correct address has already been preprinted on the reverse side of this sheet for your convenience.

Thank you for your time and cooperation. 


\section{APPENDIX B- Survey}

TOT AL QUALITY MANAGEMENT SUR VEY

Please circle the appropriate response)

ART I- DEMOGR APHICS

. GENDER-M ALE FEMALE

. STATUS-MILITARY GVILIAN

. AGE (FLL IN BLANK)

2. RACE-CAU BLACK HISPANIC ASIAN OTHER

4. PAY GRADE- E-1 TOE-4 E-5 TOE-9

O/W-1 TO 0/W-3

O/W-4 TOO-6

GS/WG-1 TO GS/WS-8

GS-9 AND ABOVE

ART II- TOM OPINIONS

(1=STRONGLY AGREE, 2=AGREE, 3=NEUTRAL, 4=DISAGREE, 5=STRONGLY DISA GREE)

. In my opinion, I feel that I need to continually improve how I do my job.

$\begin{array}{lllll}\text { SA } & \text { A } & \mathbf{N} & \mathbf{D} & \text { SD }\end{array}$

. Upper mamagement is making effective decisions to face the competitive challenges of today's health care industry. $\begin{array}{llllll}1 & 2 & 3 & 4 & 5\end{array}$

.T have to ask my boss before I do almost mything on my job.

$\begin{array}{lllll}1 & 2 & 3 & 4 & 5\end{array}$

.I want to participate (al one or with others) in making decisions that affect my work unit.

.I feel that I am well-informed about what is going on at IACH.

I feel that I am well-informed about what is going on in my department.

I am aware of the goals of the TQM program.

I woul d recommend IACH 28 a good place to work.

. I feel that the needs of our customers should al ways come first.

O. I believe that our unit climate surveys lead to worthwhile changes at IACH

1. In this organization, there is more emphasis on how much work you do rather than how well you do it.

2. My job has improved as a result of the TQM program.

3. Given the kind of work that I do, I am generally satisfied with my job.

4. During the next year, I plan to continue working at IACH.

5. I am often involved (alone or with others) in making decisions that affect my department.

6. This institution has done a good job of communicating the results of the last unit climate survey.

7. Upper management of IACH is strongly behind the TQM program.

8. I foel that there is a strong emphasis on teamwork in this arganization.

9. I underst and the TQM/ quality improvement objectives for my department.

O. My supervisor shows a strong commitment to the TQM/ quality improvement process.

1. I woul d recommend IACH to a friend or family member if they needed patient care.

2. I am satisfied with the on-going TQM training provided by IACH.

3. I have participated in a TQM program or session offered by IACH.

$\begin{array}{lllll}1 & 2 & 3 & 4 & 5\end{array}$

$\begin{array}{lllll}1 & 2 & 3 & 4 & 5\end{array}$

$\begin{array}{lllll}1 & 2 & 3 & 4 & 5\end{array}$

$\begin{array}{lllll}1 & 2 & 3 & 4 & 5\end{array}$

$\begin{array}{lllll}1 & 2 & 3 & 4 & 5\end{array}$

$\begin{array}{lllll}1 & 2 & 3 & 4 & 5\end{array}$

$\begin{array}{lllll}1 & 2 & 3 & 4 & 5\end{array}$

$\begin{array}{lllll}1 & 2 & 3 & 4 & 5\end{array}$

$\begin{array}{lllll}1 & 2 & 3 & 4 & 5\end{array}$

$\begin{array}{lllll}1 & 2 & 3 & 4 & 5\end{array}$

$\begin{array}{lllll}1 & 2 & 3 & 4 & 5\end{array}$

$\begin{array}{lllll}1 & 2 & 3 & 4 & 5\end{array}$

$\begin{array}{lllll}1 & 2 & 3 & 4 & 5\end{array}$

$\begin{array}{lllll}1 & 2 & 3 & 4 & 5\end{array}$

$\begin{array}{lllll}1 & 2 & 3 & 4 & 5\end{array}$

$\begin{array}{lllll}1 & 2 & 3 & 4 & 5\end{array}$

$\begin{array}{lllll}1 & 2 & 3 & 4 & 5\end{array}$

$\begin{array}{lllll}1 & 2 & 3 & 4 & 5\end{array}$

$\begin{array}{lllll}1 & 2 & 3 & 4 & 5\end{array}$

$\begin{array}{lllll}1 & 2 & 3 & 4 & 5\end{array}$

YES NO

DONT KNOW

4. I have participated in a qual ity improvement program or session offered by an organization other than IACH

5. My department participates in the TQM program.

YES NO

DON'T KNOW

6. I have worked with members of another depatment in a TQM/ quality improvement project (i.e., PAT).

YES NO

DON'T KNOW

7. Ihave worked within my own department on \& TQM/ quality improvement project (i.e., PET).

YES NO

DONT KNOW

8. TQM is making a positive impact within my department.

YES NO

DONT KNOW 
APPENDIX C- Table 2--Bivariate Analyses of TQM Outcomes, Mean Scores, p-value

\section{Bivariate Analyses of TQM Outcomes, Participants versus}

Nonparticipants

\begin{tabular}{|c|c|c|c|}
\hline Scale or Question & Yes & No/ Don't Know & p-value \\
\hline \multicolumn{4}{|l|}{ General Satisfaction } \\
\hline Recommend IACH to Work & 2.68 & 3.15 & .063 \\
\hline Recommend IACH for Care & 3.00 & 3.08 & .731 \\
\hline Satisfied & 3.88 & 3.86 & .924 \\
\hline Continue Working at IACH & 4.37 & 4.22 & .381 \\
\hline Effectiveness of Upper Management & 2.85 & 2.75 & .754 \\
\hline Employee Well Informed about IACH & 2.77 & 2.57 & .461 \\
\hline Employee Well Informed about Department & 3.85 & 3.37 & .091 \\
\hline \multicolumn{4}{|l|}{ Value of Survey } \\
\hline To Communicate & 2.48 & 2.68 & .339 \\
\hline To Evoke Change & 2.65 & 2.68 & .895 \\
\hline \multicolumn{4}{|l|}{ TQM Opinions } \\
\hline Continue to Improve & 4.11 & 4.06 & .843 \\
\hline Don't Need Boss' Permission & 1.88 & 2.17 & .237 \\
\hline Customer's Needs Come First & 4.28 & 4.51 & .199 \\
\hline Organization Emphasizes Quality & 3.22 & 3.26 & .876 \\
\hline Involved in Job Decisions & 3.82 & 3.06 & .007 \\
\hline Strong Emphasis on Team work & 2.74 & 2.97 & .364 \\
\hline Upper Managem ent Backs TQM & 3.20 & 3.02 & .456 \\
\hline TQM Improved Job & 2.45 & 2.62 & .458 \\
\hline Aware of TQM Goals & 3.57 & 3.15 & .084 \\
\hline Want to Participate in Decision Making & 3.51 & 3.93 & .131 \\
\hline Understand TQM Objectives for Department & 3.77 & 3.06 & .000 \\
\hline Supervisor Backs TQM & 4.02 & 3.15 & .000 \\
\hline Satisfied with TQM Training & 3.11 & 2.84 & .167 \\
\hline
\end{tabular}


APPENDIX D- Table 3--Additional Subgroup Analysis

Subgroup Analysis

\begin{tabular}{|c|c|c|c|}
\hline Subgroup & Yes & No/ Don't Know & p-value \\
\hline Age & 40 & 39 & .425 \\
\hline \multicolumn{4}{|l|}{ Gender } \\
\hline Male & $54 \%$ & $53 \%$ & .934 \\
\hline Female & $46 \%$ & $47 \%$ & .934 \\
\hline Total & $100 \%$ & $100 \%$ & \\
\hline \multicolumn{4}{|l|}{ Race } \\
\hline Caucasion & $74 \%$ & $78 \%$ & .720 \\
\hline Black & $14 \%$ & $13 \%$ & .904 \\
\hline Hišpanic & $6 \%$ & $7 \%$ & .864 \\
\hline Asian & $0 \%$ & $2 \%$ & .381 \\
\hline Other & $6 \%$ & $0 \%$ & .105 \\
\hline Total & $100 \%$ & $100 \%$ & \\
\hline \multicolumn{4}{|l|}{ Pay Grade } \\
\hline $\mathrm{E} 1$ to $\mathrm{E} 4$ & $9 \%$ & $11 \%$ & .711 \\
\hline E5 to E9 & $20 \%$ & $16 \%$ & .609 \\
\hline 01 to 03 & $6 \%$ & $4 \%$ & .799 \\
\hline 04 to 06 & $23 \%$ & $7 \%$ & .230 \\
\hline GS 1 to 8 & $23 \%$ & $44 \%$ & .045 \\
\hline GS $9 \&$ Above & $20 \%$ & $18 \%$ & .804 \\
\hline Total & $100 \%$ & $100 \%$ & \\
\hline \multicolumn{4}{|l|}{ Status } \\
\hline Military & $57 \%$ & $38 \%$ & .087 \\
\hline Civilian & $43 \%$ & $62 \%$ & .082 \\
\hline Total & $100 \%$ & $100 \%$ & \\
\hline
\end{tabular}


APPENDIX E- Table 4--Multivariate Analyses of the Effect of TQM Participation on General and TQM Opinion Indicators, Estimated Coefficients for Adjusted and Unadjusted

\begin{tabular}{|c|c|c|}
\hline \multicolumn{3}{|c|}{$\begin{array}{l}\text { Multivariate Analyses of the Effect of TQM Participation or } \\
\text { General and TQM Opinion Indicators }\end{array}$} \\
\hline Scale or Question & Adjusted & Unadjusted \\
\hline \multicolumn{3}{|l|}{ General Satisfaction } \\
\hline Recommend IACH to Work & $-.237^{*}$ & -.099 \\
\hline Recommend IACH for Care & .099 & -.009 \\
\hline Satisfied & .086 & .052 \\
\hline Continue Working at $\mathrm{IACH}$ & .100 & .131 \\
\hline Effectiveness of Upper Management & -.017 & -.001 \\
\hline Employee Well Informed about IACH & -.053 & -068 \\
\hline Employee Well Informed about Department & .084 & -.020 \\
\hline \multicolumn{3}{|l|}{ Value of Survey } \\
\hline To Communicate & -.071 & -.056 \\
\hline To Evoke Change & -.071 & .005 \\
\hline \multicolumn{3}{|l|}{ TQM Opinions } \\
\hline Continue to Improve & .029 & .077 \\
\hline Don't Need Boss' Permission & .032 & .009 \\
\hline Customer's Needs Come First & .016 & -.043 \\
\hline Organization Emphasizes Quality & .064 & .010 \\
\hline Involved in Job Decisions & .074 & .095 \\
\hline Strong Emphasis on Teamwork & -.144 & -.046 \\
\hline Upper Management Backs TQM & .146 & .038 \\
\hline TQM Improved Job & -.023 & -.101 \\
\hline Aware of TQM Goals & .172 & .108 \\
\hline Want to Participate in Decision Making & .012 & -.057 \\
\hline Understand TQM Objectives for Department & .041 & .061 \\
\hline Supervisor Backs TQM & .112 & $.188^{*}$ \\
\hline Satisfied with TQM Training & -.070 & .032 \\
\hline
\end{tabular}




\section{WORKS CITED}

Banham, Russ. "TQM Helps Hospitals Improve Care." Business \& Health 11, no. SPEISS (Annual 1993): 14-17.

Barr, Steve. "Ten Steps to Successful Implementation of Continuous Quality Improvement." The Brown University Long-Term Care Quality Letter 6, no. 10 (30 May 1994): 6-8.

Barsness, Zoe I. et al. "The Quality March: National Survey Profiles Improvement Activities." Hospitals \& Health Networks 67, no. 23 (5 December 1993): 52-55. . "The Quality March: Part Two of a National Survey of Quality Improvement Activities." Hospitals \& Health Networks 67, no. 24 (20 December 1993): 40-42.

Bendall, Dawn and Thomas L. Powers. "Cultivating Loyal Patients." Journal of Health Care Marketing 15, no. 4 (Winter 1995): 50-53.

Bennis, Warren and Burt Nanus. Leaders. New York: Harper \& Row, 1985.

Berwick, D.M. "Continuous Improvement as an Ideal in Health Care." The New England Journal of Medicine 320 (5 January 1989): 53-56.

Boerstler, Heidi, et al. "Implementation of Total Quality Management: Conventional Wisdom Versus Reality." Hospital \& Health Services Administration 41, no. 2 (Summer 1996): 143-59. 
Brown, Sam and John Williams. "North Atlantic Regional Medical Command Transition Study," November, 1996.

Counte, Michael A., Gerald L. Glandon. "Improving Hospital Performance: Issues in Assessing the Impact of TQM Activities." Hospital \& Health Services Administration 40, no. 1 (Spring 1995): 80-94.

Counte, Michael A., Gerald L. Glandon. "Total Quality Management in a Health Care Organization: How Are Employees Affected?" Hospital \& Health Services Administration 37, no. 4 (Winter 1992): 503-19.

Deming, W. Edwards. Out of the Crisis. Cambridge, MA: Massachusetts Institute of Technology, 1982. .The New Economics for Industry, Government, Education. Cambridge, MA: Massachusetts Institute of Technology, 1994.

Duffek, Elizabeth and Warren G. Harding. "Quality Management in the Military: An Overview and a Case Study." Special Libraries 84, no. 3 (Summer 1993): 137-41.

Godfrey, A.B., D.M. Berwick, and J. Roessner. "Can Quality Management Work in Health Care?" Quality Progress, April 1992, 23-27.

Johnson, J.A., W.J. Jones, and L.M. Schilling. "Quality Service Management: A Challenge for the 1990s." Journal of the American Dietetic Association 92, no. 8 (August 1992): 985-86.

Joint Commission on Accreditation of Healthcare Organizations. Striving Towards Improvement: Six Hospitals in Search of Quality. Chicago: American Publishing, 1992. 
Juran, Joseph M. Juran on Planning for Quality. New York: The Free Press, 1988. . Juran on Leadership for Quality. New York: The Free Press, 1989.

Kidder, Pamela J. and Bobbie Ryan. "How the Deming Philosophy Transformed the Department of the Navy." National Productivity Review 15, no. 3 (Summer 1996): $55-64$.

Kosta, M. "CEOs Say Hospitals Must Learn from Each Other for TQM Success." Hospitals, 20 June 1992, 42-50.

Larkin, Howard. "Higher Quality, Lower Costs." American Medical News 39, no. 18 (13 May 1996): 30-34.

Lawrence, Martin. "Caring for the Future." British Medical Journal 305, no. 6850 (15 August 1992): 400-03.

Licata, Jane W., John C. Mowen. "Diagnosing Perceived Quality in the Medical Service Channel." Journal of Health Care Marketing 15, no. 4 (Winter 1995): 42-50.

Lumsdon, Kevin. "TQM Shifts Hospital-Vendor Focus to Total Value, Productivity." Hospitals 66, no. 13 (5 July 1992): 114-17.

Maher, Lisa A. "Total Quality Management: In Its Prime or Past Its Peak?" Medical Laboratory Observer 26, no. 9 (September 1994): 22-28.

. "TQM: Successes, Failures, and Wishful Thinking." Medical Laboratory

Observer 26, no. 9 (September 1994): 28-33.

"Management Leadership Critical to CQI Success." Hospitals 66, no. 14 (20 July 1992): 64-65.

Oberman, Linda. "Quality Quandary: Little Clinical Impact Yet." American Medical News 
37, no. 16 (25 April 1994): 3-5.

Saidan, Ross. "TQM Enables Facilities to Cut Hidden Costs While Maintaining Quality Care." The Brown University Long-Term Care Quality Letter 5, no. 2 (30 January 1993): 3-5.

Schweikhart, Sharon B. and Stephen Strasser. "The Effective Use of Patient Satisfaction Data." Topics in Health Information Management 15, no. 2 (November 1994): 49-60.

Sherer, Jill L. "Hospitals Question the Return on Their TQM Investment." Hospital \& Health Networks 68, no. 7 (5 April 1994): 63-64.

Stevens, Tim. "Dr. Deming: 'Management Today Does not Know What Its Job is."' Industry Week 243, no. 2 (17 January 1994): 20-25.

"TQM Spells Financial Turnaround for Minnesota Centers." Alcoholism \& Drug Abuse Week 6, no. 18 (2 May 1994): 4-5.

Wakefield, D.S., and B. Wakefield. "Overcoming the Barriers to Implementation of TQM/ CQI in Hospitals: Myths and Realities." Quality Review Bulletin, March 1993, 83-88.

Welsh, John J. "Looking at the Big Picture Ensures TQM Success." The Brown University Long-Term Care Quality Letter 5, no. 7 (15 April 1993): 1-4.

Ziegenfuss, James T. and Patricia O'Rourke. "Ombudsmen, Patient Complaints, and Total Quality Management: An Examination of Fit." Journal of Quality Improvement 21, no. 3 (March 1995): 133-42. 


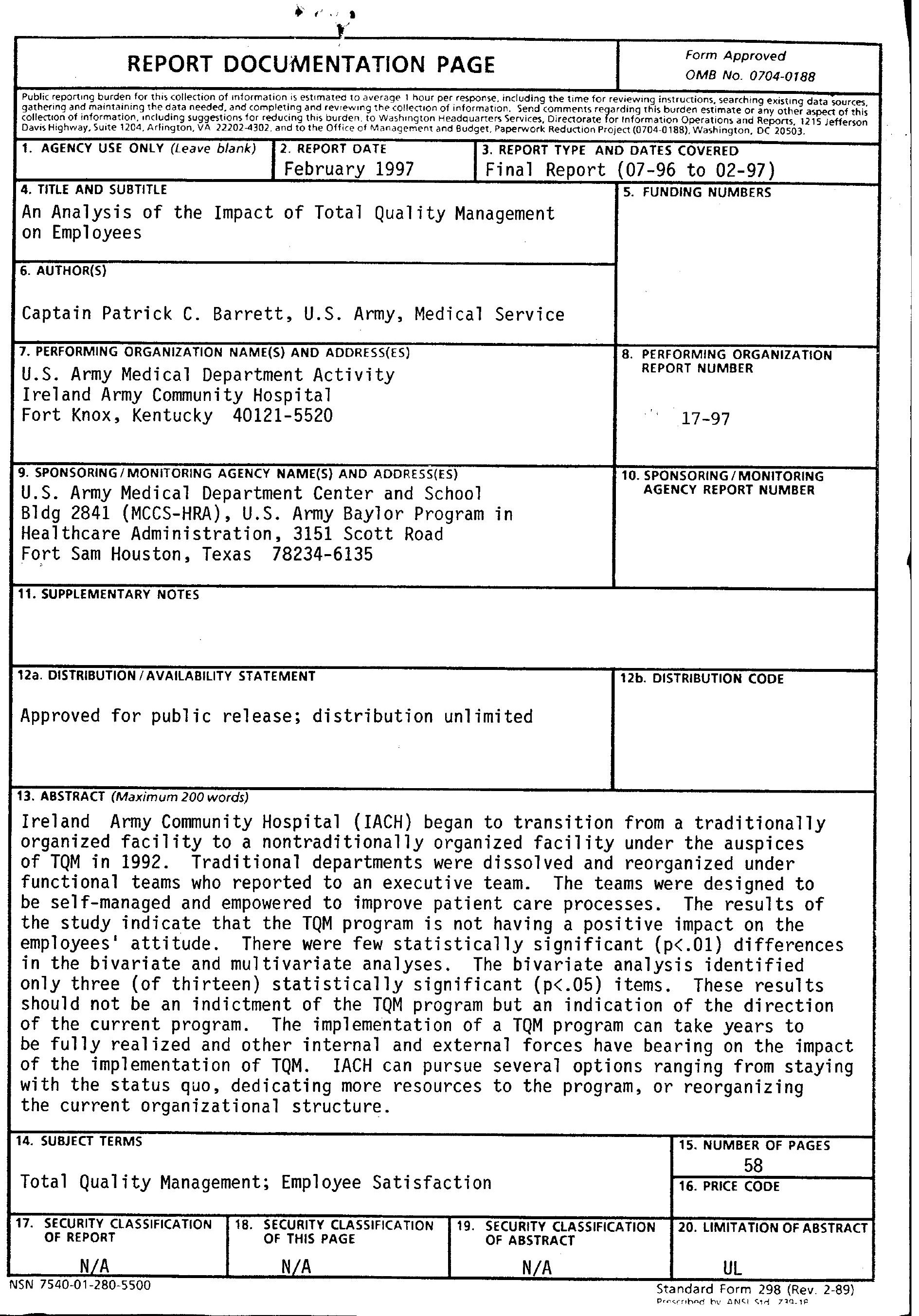

